\title{
Voltage-Gated $\mathrm{Na}^{+}$Channel $\beta 1 \mathrm{~B}$ : A Secreted Cell Adhesion Molecule Involved in Human Epilepsy
}

\author{
Gustavo A. Patino, ${ }^{1}$ William J. Brackenbury, ${ }^{1}$ Yangyang Bao, ${ }^{1}$ Luis F. Lopez-Santiago, ${ }^{1}$ Heather A. 0’Malley, ${ }^{1}$ \\ Chunling Chen, ${ }^{1}$ Jeffrey D. Calhoun, ${ }^{2}$ Ron G. Lafrenière, ${ }^{3,5}$ Patrick Cossette, ${ }^{4,6}$ Guy A. Rouleau, ${ }^{3,5}$ and Lori L. Isom ${ }^{1,2}$ \\ ${ }^{1}$ Department of Pharmacology and Program in Neuroscience, and ${ }^{2}$ Cellular and Molecular Biology Program, University of Michigan Medical School, Ann \\ Arbor, Michigan 48109, ${ }^{3}$ Centre of Excellence in Neuromics and ${ }^{4}$ Department of Medicine, Université de Montréal, Montréal, Québec H2L 2W5, Canada, \\ ${ }^{5}$ Emerillon Therapeutics, Inc., Montréal, Québec H3A IL2, Canada, and ${ }^{6}$ Centre Hospitalier de l'Université de Montréal-Hôpital Notre-Dame, Montréal, \\ Québec H2L 4M1, Canada
}

$S c n 1 b$-null mice have a severe neurological and cardiac phenotype. Human mutations in $S C N 1 B$ result in epilepsy and cardiac arrhythmia. $S C N 1 B$ is expressed as two developmentally regulated splice variants, $\beta 1$ and $\beta 1 B$, that are each expressed in brain and heart in rodents and humans. Here, we studied the structure and function of $\beta 1 \mathrm{~B}$ and investigated a novel human $S C N 1 B$ epilepsy-related mutation (p.G257R) unique to $\beta 1 \mathrm{~B}$. We show that wild-type $\beta 1 \mathrm{~B}$ is not a transmembrane protein, but a soluble protein expressed predominantly during embryonic development that promotes neurite outgrowth. Association of $\beta 1 \mathrm{~B}$ with voltage-gated $\mathrm{Na}^{+}$channels $\mathrm{Na}_{\mathrm{v}} 1.1$ or $\mathrm{Na}_{\mathrm{v}} 1.3$ is not detectable by immunoprecipitation and $\beta 1 \mathrm{~B}$ does not affect $\mathrm{Na}_{\mathrm{v}} 1.3$ cell surface expression as measured by $\left[{ }^{3} \mathrm{H}\right]$ saxitoxin binding. However, $\beta 1 \mathrm{~B}$ coexpression results in subtle alteration of $\mathrm{Na}_{\mathrm{v}} 1.3$ currents in transfected cells, suggesting that $\beta 1 \mathrm{~B}$ may modulate $\mathrm{Na}^{+}$ current in brain. Similar to the previously characterized p.R125C mutation, p.G257R results in intracellular retention of $\beta 1 B$, generating a functional null allele. In contrast, two other SCN1B mutations associated with epilepsy, p.C121W and p.R85H, are expressed at the cell surface. We propose that $\beta 1 \mathrm{~B}$ p.G257R may contribute to epilepsy through a mechanism that includes intracellular retention resulting in aberrant neuronal pathfinding.

\section{Introduction}

$S C N 1 B$ is essential for life. Deletion of $S c n 1 b$ in mice results in epilepsy, ataxia, growth retardation, cardiac abnormalities, and death (Chen et al., 2004; Lopez-Santiago et al., 2007). Human mutations in $S C N 1 B$ result in genetic epilepsy with febrile seizures plus (GEFS+) spectrum disorders (Scheffer et al., 2007; Patino and Isom, 2010), Brugada syndrome (Watanabe et al., 2008), and atrial fibrillation (Watanabe et al., 2009). Patients

Received Jan. 21, 2011; revised Aug. 10, 2011; accepted Aug. 15, 2011.

Author contributions: G.A.P., W.J.B., L.F.L.-S., J.D.C., R.G.L., P.C., G.A.R., and L.L.I. designed research; G.A.P., W.J.B., Y.B., H.A.O., C.C., J.D.C., R.G.L., and P.C. performed research; G.A.P. contributed unpublished reagents/ analytic tools; G.A.P., L.F.L.-S., C.C., J.D.C., R.G.L., P.C., G.A.R., and L.L.I. analyzed data; G.A.P., J.D.C., R.G.L., G.A.R., and L.L.I. wrote the paper.

This work was supported by NIH Grants NS064245 and MH059980 (L.LI.).) and by members of the Partnership for Pediatric Epilepsy Research, which includes the American Epilepsy Society, the Epilepsy Foundation and Parents against Childhood Epilepsy (L.L.I.). G.A.P. was supported by a predoctoral fellowship from the Epilepsy Foundation of Greater Chicago and the University of Michigan Cardiovascular Center Inaugural Predoctoral Fellowship. W.J.B. was supported by a postdoctoral fellowship from the Epilepsy Foundation. H.A.O. was supported by a postdoctoral fellowship from the University of Michigan Multidisciplinary Cardiovascular Training Program (Grant T32HL007853). J.D.C. was supported by a predoctoral fellowship from the University of Michigan Cellular Biotechnology Training Program (Grant T32-GM008353). We acknowledge the expert technical assistance of T. J. O'Shea, Raja Dondeti, Julie Jones, Guy Lenk, and Yoshihiro Morishima, and are grateful for the scientific advice of Drs. Jack Parent and Miriam Meisler.

The authors declare no competing financial interests.

Correspondence should be addressed to Dr. Lori L. Isom, Department of Pharmacology, University of Michigan Medical School, 3422 Med Sci I, SPC 5632, 1301 Catherine Street, Ann Arbor, MI 48109-5632. E-mail: lisom@umich.edu.

G. A. Patino's present address: Universidad de Los Andes Medical School, Bogotá, Colombia.

DOI:10.1523/JNEUROSCI.0361-11.2011

Copyright $\odot 2011$ the authors $\quad 0270-6474 / 11 / 3114577-15 \$ 15.00 / 0$ carrying two alleles of a $S C N 1 B$ functional null mutation, p.R125C, have Dravet syndrome, a pediatric encephalopathy associated with mental retardation that is the most severe GEFS+ spectrum disease (Patino et al., 2009). SCN1B is expressed as two splice variants, $\beta 1$ and $\beta 1 \mathrm{~B}$ (originally called $\beta 1 \mathrm{~A}$ ) that includes a retained intron encoding a novel $\mathrm{C}$ terminus, stop codon, and polyadenylation site (Kazen-Gillespie et al., 2000; Qin et al., 2003 ). Both $\beta 1$ and $\beta 1 \mathrm{~B}$ are expressed in human brain and heart. $\beta 1$ functions in current modulation, channel expression and subcellular localization, cell-cell adhesion, cellular migration, and neurite outgrowth (Brackenbury et al., 2008a,b). In contrast, little is known about the function of $\beta 1 \mathrm{~B}$. Because $S c n 1 b$-null mice lack both splice variants, some aspects of their phenotype may be due to the absence of $\beta 1 \mathrm{~B}$; however, this has not been investigated. Because all of the $S C N 1 B$ epilepsy mutations thus far are located in the Ig domain region common to both variants (Patino et al., 2009), $\beta 1 \mathrm{~B}$, as well as $\beta 1$, is likely involved in human brain disease. Our goal here was to understand the structure and function of $\beta 1 \mathrm{~B}$ and to investigate a novel human $S C N 1 B$ mutation (p.G257R) located in the region unique to $\beta 1 \mathrm{~B}$. We demonstrate that $\beta 1 \mathrm{~B}$ is not a transmembrane protein but is a soluble protein that functions as a ligand for $\beta 1$-mediated neurite outgrowth. While all four $\beta$-subunit genes have a similar exon-intron structure, only $S C N 1 B$ appears to encode variants generated by alternate splicing, with variants that include two different retained introns (Oh and Waxman, 1994; Dib-Hajj and Waxman, 1995; Kazen-Gillespie et al., 2000), suggesting complex gene regulation. $\beta 1 \mathrm{~B}$ is expressed predominantly during embryonic brain devel- 
opment, with the ratio of $\beta 1$ : $\beta 1 \mathrm{~B}$ mRNA increasing into adulthood, when $\beta 1$ becomes the major splice variant. Association of $\beta 1 \mathrm{~B}$ with voltage-gated $\mathrm{Na}^{+}$channel (VGSC) $\alpha$-subunits was not detected. However, $\beta 1 \mathrm{~B}$ coexpression results in subtle modulation of $\mathrm{Na}_{\mathrm{v}} 1$.3-generated $\mathrm{Na}^{+}$current, suggesting that this may occur in brain. Consistent with its predicted role as a cell adhesion molecule (CAM), $\beta 1 \mathrm{~B}$ stimulates neurite outgrowth through adhesion with neuronal $\beta 1$-subunits. These results support the idea that $S C N 1 B$ encoded $\beta$-subunits are key players in brain development with functions that may be unrelated to channel modulation. p.G257R results in intracellular retention of $\beta 1 \mathrm{~B}$, generating a functional null allele. We conclude that $\beta 1 \mathrm{~B}$ is a secreted CAM, expressed predominantly in embryonic brain, which stimulates neurite outgrowth. We hypothesize that the p.G257R mutation may be a risk factor for epilepsy through a mechanism that includes intracellular retention of $\beta 1 \mathrm{~B}$, resulting in aberrant neuronal migration and/or pathfinding, leading to changes in excitability.

\section{Materials and Methods}

Animals. Scn1b wild-type and null mice of either sex, congenic on the C57BL/6 background for at least 18 generations, were generated from $S c n 1 b^{+/-}$mice as described previously (Chen et al., 2004). Animals were housed in the Unit for Laboratory Animal Medicine at the University of Michigan. All procedures were performed in accordance with University of Michigan guidelines for animal use and care.

Antibodies. Primary antibodies were as follows: anti-V5 monoclonal antibody (1:1000; AbD Serotec; MCA1360, used for Western blotting; or 1:200; Invitrogen; R960-25, used for immunofluorescence), mouse or rabbit anti-pan-VGSC antibodies (1:1000; Sigma-Aldrich; S8809 or S6936, respectively), anti-protein disulfide isomerase (PDI) (1:400; Abcam), Alexa 488-conjugated goat anti-human IgG, Fc $\gamma$ fragment (1:500; Jackson ImmunoResearch), and anti- $\mathrm{Na}^{+} / \mathrm{K}^{+}$ATPase $\beta 1$-subunit antibody (1:2000; Thermo Fisher Scientific; MA1-16732). The specificity of the anti-V5 antibody in 1610 and HEK cells has been reported previously (Patino et al., 2009). Secondary antibodies were as follows: for Western blots, HRP-conjugated goat anti-rabbit or anti-mouse, diluted 1:2000 (Pierce); for immunofluorescence, goat anti-mouse or anti-rabbit secondary antibody coupled to Alexa 488 or 594 (Invitrogen), diluted 1:500.

Reverse-transcriptase PCR. Fetal frontal lobe total RNA samples (22 and 36 week gestation) were obtained from AMS Biotechnology. Postnatal frontal lobe $(n=4)$ and occipital lobe $(n=4)$ total RNA samples were kindly provided by Dr. Miriam Meisler (Department of Human Genetics, University of Michigan, Ann Arbor, MI). Total brain RNA samples from $S C N 1 B$-null mice were used as negative controls. The reverse transcriptase-PCR (RT-PCR) mix was prepared using $0.5 \mu \mathrm{g}$ of RNA as template and the Titan One Tube RT-PCR System (Roche) according to the manufacturer's instructions. The forward primer was the same for the amplification of both $\beta 1$ and $\beta 1 \mathrm{~B}$ : $5^{\prime}$-GTC GTC AAG AAG ATC CAC ATT GAG GT-3'. The reverse primer for $\beta 1$ was $5^{\prime}$-TTC GGC CAC CTG GAC GCC CGT GCA G- $3^{\prime}$ and, for $\beta 1 \mathrm{~B}$, was $5^{\prime}$-AAC CAC ACC CCG AGA AAC ACA TCG GA-3'. Steps of the RT-PCR were as follows: $50^{\circ} \mathrm{C}$ for $40 \mathrm{~s}, 94^{\circ} \mathrm{C}$ for $2 \mathrm{~min}, 30$ cycles of the following: $94^{\circ} \mathrm{C}$ for $15 \mathrm{~s}, 65^{\circ} \mathrm{C}$ for $30 \mathrm{~s}, 68^{\circ} \mathrm{C}$ for $1 \mathrm{~min}$; and then $70^{\circ} \mathrm{C}$ for $7 \mathrm{~min}$. The forward and reverse primers for $\beta 1$ were 88.5 and $88 \%$ conserved, respectively. Because the sequence of $\beta 1 \mathrm{~B}$ is species specific, there was little to no conservation between species in this region.

Quantitative PCR. Custom TaqMan MGB probes were ordered from Applied Biosystems. For $\beta 1$ (product number 4331348; AILIWI2), the forward primer was $5^{\prime}$-GGC AGA GAT GAT TTA CTG CTA CAA GA$3^{\prime}$, the reverse primer was $5^{\prime}$-GAG GTG ATG GCC AGG TAT TCC-3', and the probe primer was $5^{\prime}$-CCG CCA CGG AGA CTG-3'. For $\beta 1 \mathrm{~B}$ (product number 4331348; AIMRUPA), the forward primer was $5^{\prime}$-TCC TGC CCA CTC CAG CT-3', the reverse primer was 5'-GGG ACA GGC ATG CTT TGA C- $3^{\prime}$, and the probe primer was $5^{\prime}$-CTG GCC TCT GTT TCT C-3'. Equivalent efficiency of both sets of primers was confirmed by extracting RNA from $1610-\beta 1 V 5$ cells coexpressing $\beta 1 \mathrm{~B}$ in p.TRACER
Table 1. PCR primers used to amplify regions of the human $S C N 1 B$ gene

\begin{tabular}{llll}
\hline Exon & Forward primer sequence $\left(5^{\prime}>3^{\prime}\right)$ & Reverse primer sequence $\left(5^{\prime}>3^{\prime}\right)$ & Size (bp) \\
\hline 1 & CGCGCTCCCGGGGACATtCTAACC & CCCGGCCCCCACCCGCTGGAG & 356 \\
2 & CAATGGGGCCTCTGCCTGAC & CCCACCGCCTCCCACTCGT & 269 \\
$3 A^{a}$ & GAGAGGCCCAGGCAGTGACA & GTTCTGTACCCGGAGCGTCTGT & 527 \\
$3 B^{a}$ & CAGCCCCTCCTGCCCACTCC & CCCGCCCCAGAGGTGTTGAG & 465 \\
4 & GAGGGCCTCCAGAATGACACAGAT & CGGGCTCCGGAGTTCCTCTC & 440 \\
5 & GGGGTTGGGTGGTCTGATGATGG & AGGGCCTGAAGGGGAGCAAGAGA & 222 \\
6 & GCCGAAGTCCCCCAGGTCCCTAAT & AGGAGCTGGAGGAGGGAAAGTGG & 233 \\
\hline
\end{tabular}

For details on the $P C R$ protocols used for amplification, see Materials and Methods.

${ }^{a}$ Exon 3 was amplified in two separate minimally overlapping PCR fragments.

using Trizol (Invitrogen) according to the manufacturer's instructions. cDNA was synthesized from the extracted RNA as described below and dilutions made over a range of 5-log. Diluted cDNA was then used to perform TaqMan Gene Expression Assays in a StepOnePlus Real-Time PCR System with TaqMan Gene Expression Master Mix (both from Applied Biosystems) according to the manufacturer's instructions. $\mathrm{C}_{\mathrm{T}}$ determinations were made with the StepOne software, version 2.0 (Applied Biosystems), and used to calculate the efficiency of each primer pair. There was no statistical difference between the efficiencies of both sets of primers. Six micrograms of each sample of human RNA were incubated with DNase I (Invitrogen) following the manufacturer's instructions. cDNA was then synthesized using the SuperScript FirstStrand System (Invitrogen) according to the instructions of the manufacturer. The final volume of cDNA was then divided in 2 (for the $\beta 1$ and $\beta 1 \mathrm{~B}$ assays, respectively) and used as template for the TaqMan Gene Expression Assay using the standard cycling program. At least five repeats for each RNA sample were obtained. $\mathrm{C}_{\mathrm{T}}$ values were then used to calculate mean $\mathrm{C}_{\mathrm{T}}$ and $\mathrm{SD}$ for each sample. From the mean $\mathrm{C}_{\mathrm{T}}$ values, $2^{-\Delta \mathrm{CT}}$ were calculated for every developmental stage and SD calculated as the square $\operatorname{root}\left(\left(\mathrm{SD} \text { of } \beta 1 \mathrm{C}_{\mathrm{T}}\right)^{2}+\left(\mathrm{SD} \text { of } \beta 1 \mathrm{~B} \mathrm{C}_{\mathrm{T}}\right)^{2}\right)$.

In silico prediction of transmembrane domains and amino acid sequence alignment. Amino acid sequences of human $\beta 1$ (NP_001028.1), human $\beta 1 \mathrm{~B}$ (NP_950238.1), rat $\beta 1$ (NP_058984.1), rat $\beta 1 \mathrm{~B}$ (AAF25186.1), and mouse $\beta 1$ (NP_035452.1) were obtained from NCBI. The N-terminal region of mouse $\beta 1 / \beta 1 \mathrm{~B}$, encoded by the first three exons of $S c n 1 b$, was obtained by aligning the mouse $\beta 1$ sequence with those of the human and rat and comparing the common region to mouse chromosome 7 (AC158993.2). The unique $\mathrm{C}$-terminal region of mouse $\beta 1 \mathrm{~B}$ was obtained by translating the third intron of mouse $S c n 1 b$ in the chromosome 7 sequence. The mouse $\beta 1 \mathrm{~B}$ amino acid sequence used for analysis was the composite of the resulting $\mathrm{N}$ - and $\mathrm{C}$-terminal sequences. To predict transmembrane domains, $\beta 1$ and $\beta 1 \mathrm{~B}$ amino acid sequences were analyzed using the Goldman Engelman Steitz hydrophobicity scale, with a certain cutoff value of 1.0 and a putative cutoff value of 0.6 , using TopPred software (http://mobyle.pasteur.fr/cgi-bin/portal.py?form=toppred; Institut Pasteur) (von Heijne, 1992; Claros and von Heijne, 1994). Alignment of human, mouse, and rat $\beta 1$ and $\beta 1 \mathrm{~B}$ amino acid sequences was performed using CLUSTALW software at the Pôle Bioinformatique Lyonnais (http://npsa-pbil.ibcp.fr/cgi-bin/npsa_automat.pl?page $=$ npsa_ clustalw.html), using default settings (Thompson et al., 1994).

Expression vectors and site-directed mutagenesis. The plasmid $\beta 1 \mathrm{~V} 5$ contains a C-terminal V5-His-epitope tag and has been described previously (Patino et al., 2009). The cDNA for human $\beta 1 \mathrm{~B}$ was amplified by PCR and ligated into pTRACER-CMV2 (Invitrogen) at the EcoRI restriction site. The p.G257R mutation was introduced by site-directed mutagenesis using the QuikChange II kit (Stratagene). V5-His epitope tags were added to the $\mathrm{C}$ termini of $\beta 1 \mathrm{~B}$ and $\beta 1 \mathrm{~B}$ p.G257R cDNAs using a PCR strategy followed by ligation into pcDNA3.1/V5-His TOPO TA (Invitrogen). $\beta 1 \mathrm{~V} 5$ and $\beta 1 \mathrm{BV} 5$ cDNAs were subcloned into pcDNA3.1 Hygro $(+)$ to facilitate generation of stable cell lines. The p.R214Q, p.S248R, and p.R250T mutations were introduced into $\beta 1 B V 5 \mathrm{cDNA}$ in pcDNA3.1/V5-His by site-directed mutagenesis using the QuikChange II kit. A similar strategy was used to introduce the p.C121W and p.R85H mutations into $\beta 1 \mathrm{~V} 5 \mathrm{cDNA}$ in pcDNA3.1/V5-His. We previously described $\beta 1 \mathrm{Fc}$, a recombinant, secreted molecule containing the $\beta 1$ extracellular domain fused to the Fc region of human IgG1 (McEwen and 
Table 2. Touchdown PCR amplification conditions

\begin{tabular}{|c|c|c|c|c|c|c|c|c|c|c|}
\hline \multirow[b]{2}{*}{ Protocol } & \multirow[b]{2}{*}{$\begin{array}{l}\text { Initial } \\
\text { denaturation } \\
\text { (1 cycle) }\end{array}$} & \multicolumn{4}{|l|}{ Touchdown } & \multicolumn{4}{|l|}{ Amplification } & \multirow[b]{2}{*}{$\begin{array}{l}\text { Final } \\
\text { elongation } \\
\text { (1 cycle) }\end{array}$} \\
\hline & & $\begin{array}{l}\text { Denaturation } \\
\text { temperature } \\
(30 \mathrm{~s})\end{array}$ & $\begin{array}{l}\text { Annealing } \\
\text { temperature } \\
\text { ramp (30 s) }\end{array}$ & $\begin{array}{l}\text { Elongation } \\
\text { temperature } \\
(45 \mathrm{~s})\end{array}$ & Cycles & $\begin{array}{l}\text { Denaturation } \\
\text { temperature } \\
(30 \mathrm{~s})\end{array}$ & $\begin{array}{l}\text { Annealing } \\
\text { temperature } \\
(30 \mathrm{~s})\end{array}$ & $\begin{array}{l}\text { Elongation } \\
\text { temperature } \\
(45 \mathrm{~s})\end{array}$ & Cycles & \\
\hline TD1 & $94^{\circ} \mathrm{C}, 4 \mathrm{~min}$ & $94^{\circ} \mathrm{C}$ & $70-53^{\circ} \mathrm{C}\left(-1^{\circ} \mathrm{C}\right.$ per cycle $)$ & $72^{\circ} \mathrm{C}$ & 17 & $94^{\circ} \mathrm{C}$ & $54^{\circ} \mathrm{C}$ & $72^{\circ} \mathrm{C}$ & 25 & $72^{\circ} \mathrm{C}, 5 \mathrm{~min}$ \\
\hline TD3 & $94^{\circ} \mathrm{C}, 4 \mathrm{~min}$ & $94^{\circ} \mathrm{C}$ & $70-60^{\circ} \mathrm{C}\left(-1^{\circ} \mathrm{C}\right.$ per cycle $)$ & $72^{\circ} \mathrm{C}$ & 10 & $94^{\circ} \mathrm{C}$ & $60^{\circ} \mathrm{C}$ & $72^{\circ} \mathrm{C}$ & 30 & $72^{\circ} \mathrm{C}, 5 \mathrm{~min}$ \\
\hline TD8 & $94^{\circ} \mathrm{C}, 4 \mathrm{~min}$ & $94^{\circ} \mathrm{C}$ & $66-59^{\circ} \mathrm{C}\left(-0.5^{\circ} \mathrm{C}\right.$ per cycle $)$ & $72^{\circ} \mathrm{C}$ & 14 & $94^{\circ} \mathrm{C}$ & $58^{\circ} \mathrm{C}$ & $72^{\circ} \mathrm{C}$ & 25 & $72^{\circ} \mathrm{C}, 5 \mathrm{~min}$ \\
\hline TD10 & $94^{\circ} \mathrm{C}, 4 \mathrm{~min}$ & $94^{\circ} \mathrm{C}$ & $70-63^{\circ} \mathrm{C}\left(-0.5^{\circ} \mathrm{C}\right.$ per cycle $)$ & $72^{\circ} \mathrm{C}$ & 14 & $94^{\circ} \mathrm{C}$ & $62^{\circ} \mathrm{C}$ & $72^{\circ} \mathrm{C}$ & 25 & $72^{\circ} \mathrm{C}, 5 \mathrm{~min}$ \\
\hline TD11 & $94^{\circ} \mathrm{C}, 4 \mathrm{~min}$ & $94^{\circ} \mathrm{C}$ & $72-65^{\circ} \mathrm{C}\left(-0.5^{\circ} \mathrm{C}\right.$ per cycle $)$ & $72^{\circ} \mathrm{C}$ & 14 & $94^{\circ} \mathrm{C}$ & $64^{\circ} \mathrm{C}$ & $72^{\circ} \mathrm{C}$ & 25 & $72^{\circ} \mathrm{C}, 5 \mathrm{~min}$ \\
\hline
\end{tabular}

Isom, 2004). To generate a stable $\beta 1 F c$-producing cell line, cDNA encoding the extracellular domain of rat $S c n 1 b$ was ligated into pINFUSEhIgG1-Fc1 (Invitrogen). The integrity of all plasmids was confirmed by DNA sequencing at the University of Michigan DNA Sequencing Core. PCR primers and conditions for all reactions are available upon request. The cDNA for human $\mathrm{Na}_{\mathrm{v}} 1.5$ corresponding to the $\mathrm{hH} 1$ polymorphism (GenBank accession number M77235) (Makielski et al., 2003) in pRcCMV (Invitrogen) was provided by Dr. Al George (Division of Genetic Medicine and Vanderbilt Institute for Integrative Genomics, Vanderbilt University, Nashville, TN).

Cell lines. All cell lines were maintained at $37^{\circ} \mathrm{C}$ with $5 \% \mathrm{CO}_{2}$. Chinese hamster lung 1610 cells stably transfected with $\mathrm{Na}_{\mathrm{v}} 1.5\left(1610 \mathrm{hNa}_{\mathrm{v}} 1.5\right), \beta 1 \mathrm{~V} 5$, or $\beta 1 \mathrm{BV} 5$ were cultured in DMEM with low glucose, L-glutamine, and sodium pyruvate supplemented with $5 \%$ heat-inactivated fetal bovine serum (HI-FBS), $100 \mathrm{U}$ plus $100 \mu \mathrm{g} / \mathrm{ml}$ penicillin/streptomycin, $400 \mu \mathrm{g} / \mathrm{ml}(2 R, 3 S, 4 R, 5 R, 6 S)-5-$ amino-6-[( $1 R, 2 S, 3 S, 4 R, 6 S)$-4,6-diamino-3-[(2R,3R,4R,5R)-3,5-dihydroxy-5-methyl-4-methylaminooxan-2-yl] oxy-2-hydroxycyclohexyl] oxy-2-(1-hydroxyethyl)oxane-3,4-diol (G418), and $0.25 \mu \mathrm{g} / \mathrm{ml}$ Fungizone (all from Invitrogen). HEK-293 cells expressing human $\mathrm{Na}_{\mathrm{v}} 1.1$ (GenBank accession number NP_008851.3; HEKhNa ${ }_{v} 1.1$ ) were obtained from GlaxoSmithKline under a materials transfer agreement and maintained in DMEM supplemented with $10 \% \mathrm{HI}-\mathrm{FBS}, 400 \mu \mathrm{g} / \mathrm{ml} \mathrm{G} 418,1 \%$ nonessential amino acids, $100 \mathrm{U}$ plus $100 \mu \mathrm{g} / \mathrm{ml}$ penicillin/streptomycin, and $0.25 \mu \mathrm{g} / \mathrm{ml}$ Fungizone. Chinese hamster ovary cells stably expressing human $\mathrm{Na}_{\mathrm{v}} 1.3$ (GenBank accession number NP_008853.3; $\mathrm{CHOhNa}_{\mathrm{v}} 1.3$ ) were provided by Dr. David Ragsdale (Montreal Neurological Institute, Montreal, QC, Canada) and maintained in $1 \times$ Iscove's modified Dulbecco's medium with L-glutamine and $25 \mathrm{~mm}$ HEPES, supplemented with 10\% HI-FBS, $400 \mu \mathrm{g} / \mathrm{ml}$ G418, 1\% nonessential amino acids, $100 \mathrm{U}$ plus $100 \mu \mathrm{g} / \mathrm{ml}$ penicillin/ streptomycin, and 1\% HT supplement (Invitrogen).

For transient transfection of $\mathrm{HEKhNa}_{\mathrm{v}} 1.1$ cells (Fugene 6; Roche), 7.5 $\mu \mathrm{g}$ of cDNA encoding $\beta 1 \mathrm{~V} 5$ or $\beta 1 \mathrm{BV} 5$ were used. Twenty-four to $48 \mathrm{~h}$ later, cells were collected for experiments.

To generate stable cell lines, $2.5 \mu \mathrm{g}$ of $\beta$-subunit cDNAs were transfected (Fugene 6 ), and $24 \mathrm{~h}$ later cells were passaged into fresh medium containing selective antibiotics: G418 $(400 \mu \mathrm{g} / \mathrm{ml})$ for $\mathrm{Na}_{\mathrm{v}} 1.5$ or V5-Histagged $\beta$-subunit cDNAs; Hygromycin $(400 \mu \mathrm{g} / \mathrm{ml})$ for V5-His-tagged $\beta$-subunit cDNAs transfected into cell lines stably expressing $\alpha$-subunits; Zeocin $(400 \mu \mathrm{g} / \mathrm{ml})$ for wild-type or mutant $\beta 1 \mathrm{~B}$-subunit cDNAs in pTRACER-CMV 2 or for the generation of the $\beta 1 F c$ cell line. Antibioticresistant colonies were isolated and characterized as described previously (Isom et al., 1995). To confirm stable transfection of pTRACER-CMV2 vectors, cells were plated in eight-chamber polystyrene vessel tissue culture-treated glass slides (Falcon; BD Biosciences Discovery Labware), rinsed with $1 \times$ PBS (Invitrogen), and fixed with $4 \%$ paraformaldehyde for $20 \mathrm{~min}$ at room temperature (RT). The slides were mounted on glass coverslips using Gel/Mount (Biomeda) and viewed using a Fluoview 500 confocal laser-scanning microscope (Olympus) with $100 \times$ objective. Images $(1024 \times 1024$ pixels $)$ were acquired with the Olympus Optical Fluoview software. To edit the figures for this study, images were exported to Adobe Photoshop CS3 Extended, version 10.0.1. Other than cropping, no other changes were made to the images.

Detection of $\beta 1 V 5$ or $\beta 1 B V 5$ by immunofluorescence. Cells expressing $\beta 1 \mathrm{~V} 5, \beta 1 \mathrm{Fc}, \beta 1 \mathrm{BV} 5$ alone, or hNav1.5 plus $\beta 1 \mathrm{BV} 5$ were used for immunofluorescent staining. Cells on glass coverslips or on eight-chamber slides were fixed briefly with $4 \%$ paraformaldehyde and washed 3 times
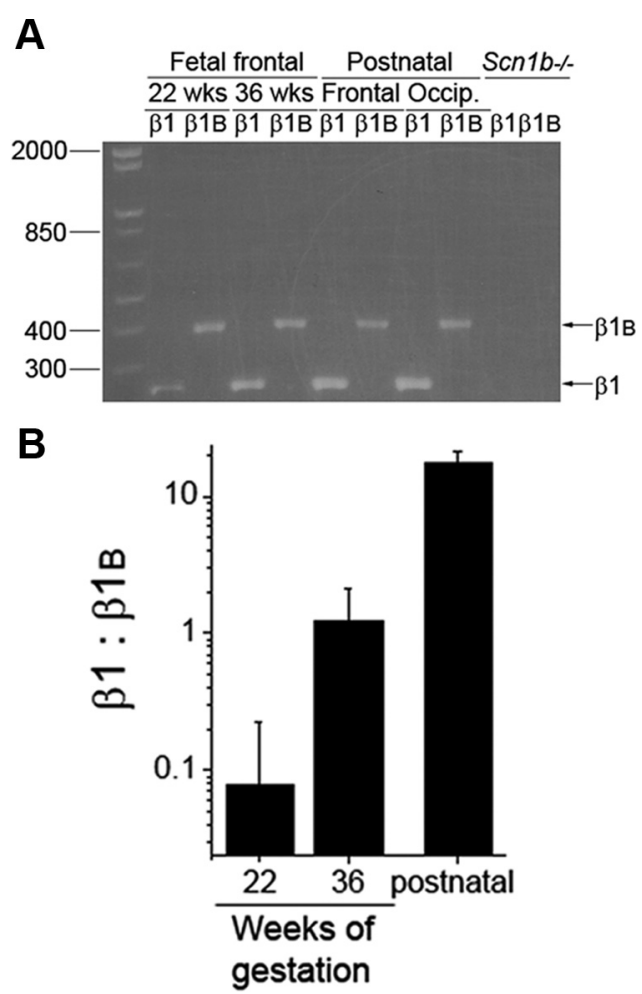

Figure 1. $\quad \beta 1 B$ is the predominant SCN1B splice variant during human fetal brain development. $\boldsymbol{A}$, Reverse transcriptase-PCR using primers for $\beta 1$ or $\beta 1 \mathrm{~B}$ performed with total RNA as template from human embryonic frontal lobe (22 week gestation, lanes 1 and 2; or 36 week gestation, lanes 3 and 4), postnatal frontal lobe (lanes 5 and 6 ), or postnatal occipital lobe (lanes 7 and 8). Samples of total RNA from Scn1b-null mouse brain were analyzed in parallel as negative controls (lanes 9 and 10). The gel shown is representative of triplicate experimental repeats. Nucleic acid markers are shown in base pairs. The arrows indicate $\beta 1$ and $\beta 1 B$ bands. $\boldsymbol{B}$, Quantitative PCR was performed with cDNAs generated from the RNA frontal lobe samples using the TaqMan assay as described in Materials and Methods. Ratios of $\beta 1$ to $\beta 1 B$ were compared using the $2^{-\Delta C T}$ method for each time point. Values are presented as mean \pm SD. Note the logarithmic scale on the $y$-axis.

with 0.05 M phosphate buffer (PB) before use. Cells were permeabilized for a minimum of $1 \mathrm{~h}$ in PBTGS (0.1 м PB, 0.3\% Triton X-100, and $10 \%$ normal goat serum) and incubated overnight with primary antibodies diluted in PBTGS. The following day, cells were incubated for $2 \mathrm{~h}$ in goat anti-mouse secondary antibody coupled to Alexa 594 (Invitrogen) diluted in PBTGS. Alternately, some cells were incubated with Alexa 488conjugated anti-human IgG, Fc $\gamma$ fragment antibody diluted in PBTGS for $2 \mathrm{~h}$. Samples were washed three times with $0.1 \mathrm{M}$ PB after each antibody step. Cells were incubated with DAPI for $20 \mathrm{~min}$ and washed again with $0.1 \mathrm{M}$ PB. Samples were air-dried and mounted onto SuperFrost Plus slides using ProLong Gold antifade reagent with DAPI (Invitrogen). Digital images were collected using a Nikon A1R confocal microscope with Nikon NIS-Elements software located in the Department of Pharmacology, University of Michigan. 
Western blot analysis. For each experiment, stably transfected cells from a $100 \mathrm{~mm}$ Petri dish, or transiently transfected cells from a 60 $\mathrm{mm}$ dish (at 95\% confluence), were prepared for Western blot analysis as described previously (Patino et al., 2009). Western blot analysis was performed using the SNAP i.d. Protein Detection System (Millipore) according to the instructions of the manufacturer. All results presented are representative of at least three experimental repeats.

Surface biotinylation. Transfected cells were grown in four tissue culture plates $(60 \mathrm{~mm}$ dishes for transiently transfected or $100 \mathrm{~mm}$ dishes for stably transfected cell lines) and membrane proteins biotinylated using the Cell Surface Labeling Accessory Pack (Thermo Fisher Scientific) following the manufacturer's instructions with Complete Mini (Roche) as protease inhibitor. Samples were loaded on a $10 \%$ SDS-PAGE gel and processed for Western blot. Immunoreactive signals were quantified using NIH ImageJ software and normalized to the level of $\mathrm{Na}^{+} / \mathrm{K}^{+}$ATPase $\beta 1$-subunit, a cell surface protein. All results presented are representative of at least three repeats.

Coimmunoprecipitation. Two hundred microliters of protein G-Sepharose 4B beads (Sigma-Aldrich) per sample of $\alpha$ plus $\beta 1$ or $\alpha$ plus $\beta 1 \mathrm{~B}$ cell lines were rinsed three times with $1 \times$ PBS and split into two microcentrifuge tubes. Beads were resuspended in $250 \mu \mathrm{l}$ of dilution buffer (60 mm Tris-HCl, pH 7.5, $180 \mathrm{~mm}$ $\mathrm{NaCl}, 1.25 \%$ Triton X-100, 6 mм EDTA, pH 8, with Complete Mini Protease Inhibitor Tablets) and incubated overnight with end-overend mixing at $4^{\circ} \mathrm{C}$ with $4 \mu \mathrm{g}$ of mouse or rabbit pan-VGSC antibody or $4 \mu \mathrm{g}$ of mouse or rabbit $\mathrm{IgG}$, as indicated in the figure legends. Cells coexpressing $\alpha$-plus $\beta$-subunits were resuspended in a $50 \mathrm{~mm}$ Tris, $10 \mathrm{~mm}$ EGTA, pH 8 solution (with Complete Mini) by scraping. The amount of sample used for each cell line was as follows: for $\mathrm{HEKhNa}_{\mathrm{v}} 1.1$ cells transiently transfected or $\mathrm{HEKhNa}_{\mathrm{v}} 1.5$ cells stably transfected with $\beta 1$ or $\beta 1 \mathrm{~B}$, one $60 \mathrm{~mm}$ cell culture dish; for $\mathrm{CHOhNa}_{\mathrm{v}} 1.3$ cells stably transfected with $\beta 1$ or $\beta 1 \mathrm{~B}$, two $100 \mathrm{~mm}$ cell culture dishes. Cell suspensions were then centrifuged at $3000 \times g$ for $10 \mathrm{~min}$ at $4^{\circ} \mathrm{C}$. Cells were washed again in Tris/EGTA solution, resuspended in $1 \mathrm{ml}$ of dilution buffer, and incubated $30 \mathrm{~min}$ on ice for lysis. After a centrifugation step to remove insoluble material, one-half of the supernatant was added to the beads incubated with anti-pan-VGSC antibody and the other one-half to the beads incubated with IgG. Beads with cell lysates were incubated with end-over-end mixing for $4 \mathrm{~h}$ at $4^{\circ} \mathrm{C}$, and then washed three times with washing buffer (50 mm Tris, pH 7.5, $150 \mathrm{~mm} \mathrm{NaCl}, 0.1 \%$ Triton X-100, 0.02\% SDS, 5 mм EDTA, pH 8, with Complete Mini) and once with washing buffer without Triton $\mathrm{X}-100$. Thirty-five microliters of Western blot sample buffer were then added to the beads, triturated, and incubated at $100^{\circ} \mathrm{C}$ for $5 \mathrm{~min}$. Samples were then separated by SDS-PAGE on 10 or $18 \%$ polyacrylamide gels and transferred to nitrocellulose membranes for Western blot analysis.

Purification of $\beta 1 B$ from conditioned media. Cells stably expressing V5-His epitope-tagged subunits were grown in one $850 \mathrm{~cm}^{2}$ polystyrene

C

150

Mouse

E $\beta 1$
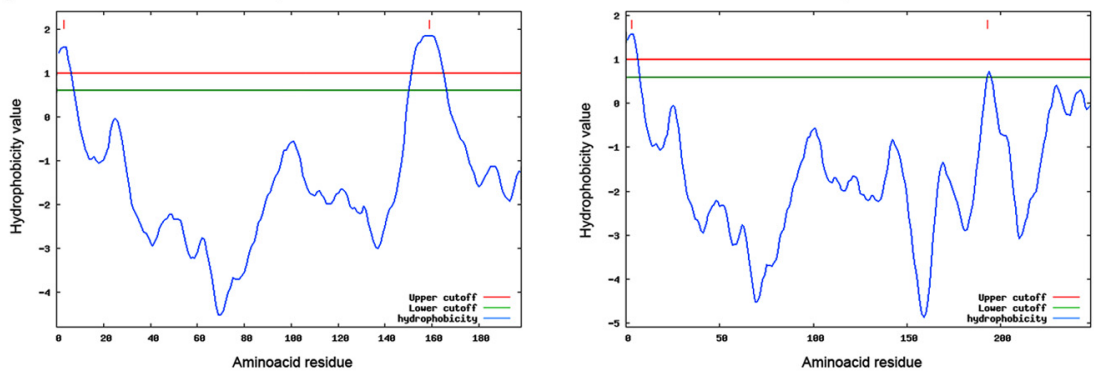

Human a

Rat ANRDMASIVSEIMMYVL IVVLT WLVAEMVYCYKKIAAATEAAAQENASEYLAITSESKEVCTGVQVAE

Mouse ANRDMASIVSEIMMYVL IVVLTIWLVAEMVYCYKKIAAATEAAAQENASEYLAITSESKENCTGVQVAE

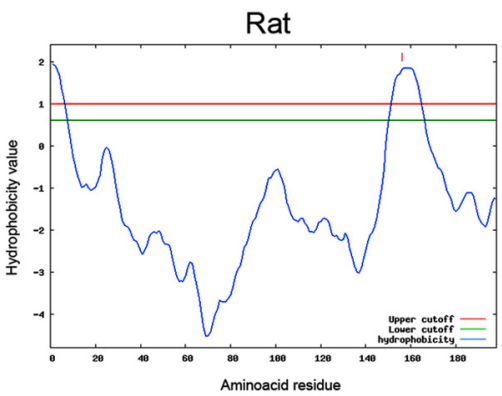

Human GESGAACPFTVTHRRARWRDRWOAVDRTGWLCAWPANRPQORAEGEGSSPSCPLOLWPLFLSSPRRGOSM

Rat GKWSLVTLW-----QARWRDRWKEGDR---LVSHRGQLTPRSHRGK-DTPFLVLETSALQHTGGQIRTPT

Mouse GESSLVTPW-----QARWRDRWKVGDR---LVPHRGQLTPCSHREK-DTPFLALESSAHRRLD-----*: . . : : :******* ** * . . : . . : . .* * :

220

Rat PPPTN--GMCIGL-HSCCVTSDGCIPISEPQACPQGPERIFCMACCVSQAGPHWRDVGTYLRPQWE

Rat
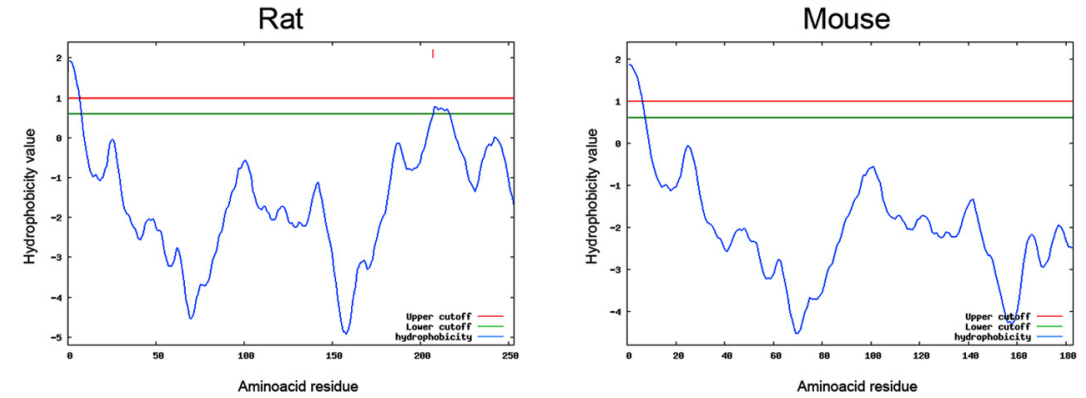

Figure 2. Hydrophobicity analysis of $\beta 1$ and $\beta 1 \mathrm{~B}$. $A$, Hydrophobicity plots analyzing the amino acid sequences of human $\beta 1$ (left panel) or $\beta 1 \mathrm{~B}$ (right panel) show identical $\mathrm{N}$-terminal signal peptides. $\beta 1$, but not $\beta 1 \mathrm{~B}$, contains a transmembrane domain. $\boldsymbol{B}$, The $C$-terminal region of $\beta 1$ is conserved between species. Alignments of the predicted amino acid sequences of the $C$-terminal region of $\beta 1$ encoded by exons 4 and 5 in human, rat, and mouse using the CLUSTALW algorithm. Numbers above all alignment correspond to the human sequence. $C$, Hydrophobicity plots analyzing the amino acid sequences of rat $\beta 1$ (left panel) or mouse $\beta 1$ (right panel) show predicted hydrophobic signal peptide and transmembrane domains. $\boldsymbol{D}$, The unique (-terminal region of $\beta 1 B$ is not conserved between species. Alignments of the predicted amino acid sequences of the unique C-terminal region of $\beta 1 \mathrm{~B}$ encoded by retained intron 3 in human, rat, and mouse using the CLUSTALW algorithm. Numbers above all alignments correspond to the human sequence. $\boldsymbol{E}$, Hydrophobicity plots analyzing the amino acid sequences of rat $\beta 1 \mathrm{~B}$ (left panel) or mouse $\beta 1 \mathrm{~B}$ (right panel) show hydrophobic signal peptides but no transmembrane domains.

roller bottle (Corning) containing $50 \mathrm{ml}$ of media, or in $12150 \times 25 \mathrm{~mm}$ cell culture dishes (Corning) containing $20 \mathrm{ml}$ of media per dish until confluent $(8-15 \mathrm{~d})$. The medium was not changed during this period but was supplemented with $1-2 \mathrm{ml}$ of HI-FBS every 3-4 d. When cells reached confluence, conditioned media were collected and centrifuged to pellet cells that may have detached. The media were concentrated using a Millipore stirred cell concentrator, with a regenerated cellulose ultrafil- 
tration membrane (nominal molecular weight limit, 10,000) (Millipore) to obtain a volume of $\sim 50 \mathrm{ml}$. Complete EDTA-free Protease Inhibitor Cocktail (Roche) was added to prevent degradation. Concentrated conditioned media were mixed with $1.2 \mathrm{ml}$ total volume of His-Select HF Nickel Affinity Gel (Sigma-Aldrich), previously rinsed with deionized water and equilibration/washing buffer $\left(50 \mathrm{mM} \mathrm{NaH}_{2} \mathrm{PO}_{4}, \mathrm{pH} 8.0,300\right.$ $\mathrm{mm} \mathrm{NaCl}, 10 \mathrm{~mm}$ imidazole) in a Poly-Prep Chromatography Column (Bio-Rad), and incubated for $30 \mathrm{~min}$ at RT on a Clay Adams Nutator Mixer (BD Biosciences). The mix was then centrifuged at maximum speed in a swinging bucket rotor for $5 \mathrm{~min}$. The supernatant was discarded, and the nickel gel was resuspended in $15 \mathrm{ml}$ of equilibration/ washing buffer. This washing step was repeated until the supernatant after centrifugation was completely clear. The nickel gel was resuspended in equilibration/washing buffer and transferred to the chromatography column in which the gel had been prerinsed. The nickel gel was then washed with $10 \mathrm{ml}$ of equilibration/washing buffer, followed by elution buffer (50 $\mathrm{mm} \mathrm{NaH}_{2} \mathrm{PO}_{4}, \mathrm{pH} 8.0,300 \mathrm{~mm} \mathrm{NaCl}, 250 \mathrm{~mm}$ imidazole), and the eluted fraction was collected in a Millipore Ultra-4 Centrifugal Filter Device with a 10,000 molecular weight cutoff regenerated cellulose filter (Millipore). The filter device was centrifuged at top speed in a swinging bucket rotor for $25 \mathrm{~min}$, and the nonfiltered fraction was collected in a microcentrifuge tube where it was mixed with loading buffer containing SDS and $\beta$-mercaptoethanol at a 1:1 ratio. Western blot analysis was then performed. All results presented are representative of at least three repeats.

Cerebellar granule neuron neurite outgrowth assays. Neurite outgrowth assays from P14 mouse cerebellar granule neurons (CGNs) were described previously (Davis et al., 2004). Neurite length measurements were obtained from a minimum of 50 cells per condition from at least three independent experiments. Data from individual experiments were combined to provide an overall mean and SEM.

$\left[{ }^{3} \mathrm{H}\right]$ Saxitoxin binding. $\left[{ }^{3} \mathrm{H}\right]$ Saxitoxin $\left(\left[{ }^{3} \mathrm{H}\right] \mathrm{STX}\right)$ binding was performed on intact cells, analyzed, and normalized to total cellular protein as previously described (McEwen et al., 2004).

Deglycosylation. Five microliters of whole-cell lysate from 1610- $\beta 1 \mathrm{BV} 5$ were treated with PGNase F (New England Biolabs; P0704S) following the instructions of the manufacturer. After enzymatic deglycosylation, the sample was mixed with Western blot sample buffer, separated by SDS-PAGE on a $10 \%$ polyacrylamide gel, and transferred to nitrocellulose for Western blot analysis. Another $5 \mu \mathrm{l}$ aliquot of untreated wholecell lysate was included on the Western blot as a negative control.

Whole-cell patch-clamp recording and analysis. Micropipettes were obtained from capillary glass tubing (Warner Instruments) using a horizontal P-97 puller (Sutter Instrument). Micropipettes resistance was between 1.5 and $3.5 \mathrm{M} \Omega$, when filled with intracellular solution containing the following (in mM): $10 \mathrm{NaCl}, 20 \mathrm{CsF}, 95 \mathrm{CsCl}, 10 \mathrm{EGTA}$, and 10 HEPES, pH 7.4 with $\mathrm{CsOH}$; and the extracellular solution containing the following (in $\mathrm{mm}$ ): $60 \mathrm{NaCl}, 4 \mathrm{KCl}, 1.5 \mathrm{CaCl}_{2}, 1 \mathrm{MgCl}_{2}, 5$ glucose, 10 HEPES, $70 \mathrm{CsCl}$, pH 7.4 with $\mathrm{NaOH}$. Voltage pulses were applied, and data were recorded using Clampex 9.2, Axopatch 200B amplifier, and a Digidata 1322A digitizer (Molecular Devices). Pipette and whole-cell capacitance were fully compensated. When appropriate, series resistance compensation was set to $\sim 40-70 \%$ with the lag set to $10 \mu \mathrm{s}$. Signals were low-pass filtered at $5 \mathrm{kHz}$, and data were sampled at $40 \mathrm{kHz}$ on-line. To determine the $\mathrm{Na}^{+}$current amplitude and voltage dependence of activation, $\mathrm{Na}^{+}$currents were evoked by depolarization to different $250 \mathrm{~ms}$ test pulses (from -110 to $-70 \mathrm{mV}$ at $10 \mathrm{mV}$ intervals, from -70 to -10 $\mathrm{mV}$ at $5 \mathrm{mV}$ intervals, and from -10 to $40 \mathrm{mV}$ at $10 \mathrm{mV}$ intervals) from a holding potential of $-80 \mathrm{mV}$ and a hyperpolarizing $-120 \mathrm{mV}, 500 \mathrm{~ms}$ prepulse. Peak $\mathrm{Na}^{+}$current was normalized to cell capacitance and used to plot $I-V$ curves and calculate conductance $\left[g=I /\left(V-V_{\text {rev }}\right)\right.$, where $V$ is the test potential, and $V_{\text {rev }}$ is the measured reversal potential]. Voltage dependence of inactivation was determined by applying a $50 \mathrm{~ms}$ test pulse of $0 \mathrm{mV}$ after $250 \mathrm{~ms}$ prepulses to the same voltages as described for the voltage dependence of activation. Peak currents were normalized to the maximum peak $I_{\mathrm{Na}}$ amplitude. Normalized activation and inactivation curves were fit with a Boltzmann equation, $1 /\left[1+\exp \left(V-V_{1 / 2}\right) / \kappa\right]$, where $V_{1 / 2}$ is the membrane potential in the midpoint of the curve, and $\kappa$ is the slope factor. To assess the time course of recovery from inactiva-
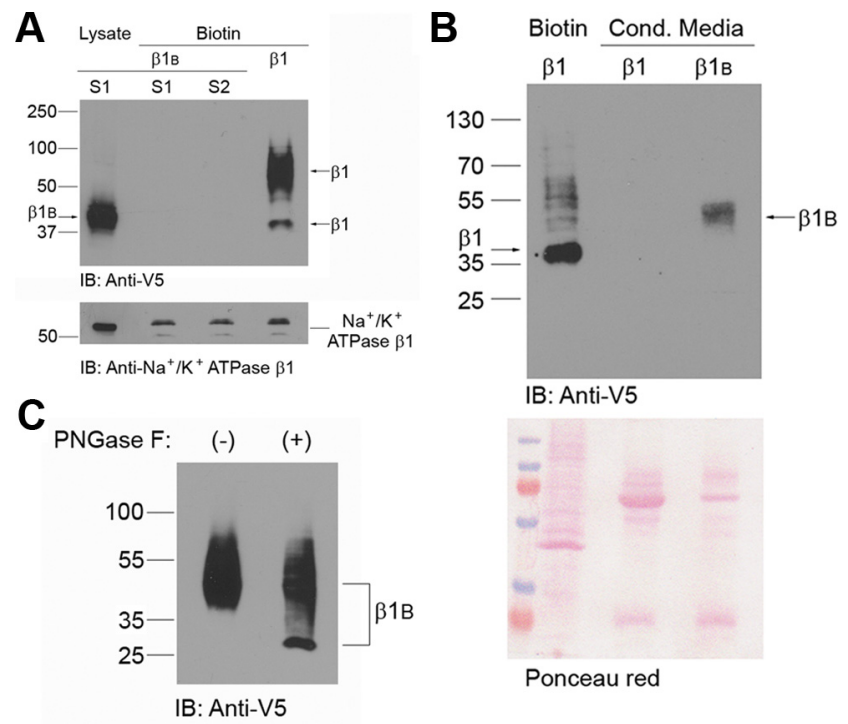

Figure 3. $\beta 1 \mathrm{~B}$ is a secreted protein. $A, \beta 1$ but not $\beta 1 \mathrm{~B}$ is expressed at the cell surface Western blot showing surface biotinylation of 1610 cells stably transfected with V5-His-tagged $\beta 1 \mathrm{~B}(\beta 1 \mathrm{~B})$ or V5-His-tagged $\beta 1$ ( $\beta 1$ ) (top panel). Robust $\beta 1 \mathrm{~B}$ expression was observed in the whole-cell lysate (Lysate $S 1)$. This same cell clone (S1) was assayed by surface biotinylation (Biotin S1), showing the absence of $\beta 1 B$ at the cell surface. An independent $\beta 1 B-V 5$ clone (S2) gave a similar result. A biotinylated sample from 1610 cells stably transfected with V5-Histagged $\beta 1$ (Biotin $\beta 1$ ) was used as positive control for cell surface expression. A Western blot of the same samples with anti-Na ${ }^{+} / K^{+}$ATPase $\beta 1$ showed equal loading of surface proteins (bottom panel). $\boldsymbol{B}, \beta 1 \mathrm{~B}$ but not $\beta 1$ is expressed in conditioned media. Top panel, Conditioned media from 1610 cells stably expressing $\beta 1 V 5$ (Cond. Media $\beta 1$ ) or $\beta 1$ BV5 (Cond. Media $\beta 1 B$ ) were analyzed by Western blot and probed with anti-V5. A surface biotinylated sample of $1610-\beta 1 V 5$ cells (Biotin $\beta 1$ ) is a positive control. Bottom panel, Ponceau red staining of the membrane demonstrates protein in all lanes. $C, \beta 1 B$ is a glycoprotein. Western blot of $1610-$ $\beta 1$ BV5 whole-cell lysates before (left lane) and after (right lane) treatment with PNGase F. The bottom immunoreactive band is consistent with the molecular weight of fully deglycosylated $\beta 1 \mathrm{~B}(\sim 26 \mathrm{kDa})$. All blots are representative of three experimental repeats. Molecular weight markers are given in kilodaltons. The arrows indicate $\beta 1$ - or $\beta 1 \mathrm{~B}$-immunoreactive bands.

tion, a prepulse to $0 \mathrm{mV}$ for $20 \mathrm{~ms}$ was followed by a recovery interpulse of variable duration (from 0.25 to $750 \mathrm{~ms}$ ) to $-120 \mathrm{mV}$ and then a $25 \mathrm{~ms}$ test pulse to $0 \mathrm{mV}$ to determine the fraction of recovered channels. Peak $\mathrm{Na}^{+}$currents during the test pulse were normalized to the peak $\mathrm{Na}^{+}$ current during the corresponding prepulse and plotted as fractional recovery $\left(F_{\mathrm{r}}\right)$ against time. Data were then fit with one exponential to determine the time constants for recovery, using the equation $F_{\mathrm{r}}=1-$ $\exp ((-x) / \tau)$, where $\tau$ is the constant of recovery. The kinetics of inactivation was measured on the test pulse to $0 \mathrm{mV}$ from the same protocol used for voltage dependence of activation. The current, from $90 \%$ of the peak amplitude to $20 \mathrm{~ms}$ after the test pulse was initiated, was fitted to a double-exponential equation of the form $I=\left(F_{\mathrm{f}}{ }^{*} \exp \left(-t / \tau_{\mathrm{f}}\right)\right)+$ $\left(F_{\mathrm{s}}^{*} \exp \left(-t / \tau_{\mathrm{s}}\right)+C\right.$, using the Chebyshev method, where $I$ is the current, $\tau_{\mathrm{f}}$ and $\tau_{\mathrm{s}}$ are the time constants for the fast and slow inactivation component, and $C$ is the steady-state persistent current. Analysis of the recorded $\mathrm{Na}^{+}$current was performed using the software packages Clampfit 9.0.2 (Molecular Devices) and SigmaPlot 11.2 (Systat Software).

Clinical samples. A group of 360 unrelated probands [122 males (m) and 238 females (f)] diagnosed with epilepsy ( $n=118 ; 42 \mathrm{~m}, 76 \mathrm{f})$, migraine ( $n=110 ; 23 \mathrm{~m}, 87 \mathrm{f})$, Tourette's syndrome $(n=35 ; 23 \mathrm{~m}, 12 \mathrm{f})$, essential tremor $(n=25 ; 7 \mathrm{~m}, 18 \mathrm{f})$, bipolar disorder $(n=66 ; 24 \mathrm{~m}$, $42 \mathrm{f})$, episodic ataxia $(n=4 ; 3 \mathrm{~m}, 1 \mathrm{f})$, episodic vertigo $(n=1 \mathrm{f})$, or episodic fainting ( $n=1 \mathrm{f}$ ) were studied. Subjects were ascertained on the basis of family studies and routine clinical practice. Diagnoses were performed by clinicians specialized in these neurological disorders. For most patients, additional clinical information allowed for a better definition of the disease subphenotype, especially in cases of epilepsy, bipolar disorder, and migraine. The ethnic origin of all subjects is known, and additional affected and nonaffected family members for each proband 
studied were collected for cosegregation/pedigree analysis. Informed consent was obtained from all participants, and study protocols were approved by the ethics committees of the institutions where collections occurred. An additional cohort of 192 unrelated Tourette's patient samples ( $150 \mathrm{~m}, 42 \mathrm{f}$ ) was used to assess involvement of the p.G257R variant in Tourette's syndrome.

Amplicon design and PCR for patient samples. Amplicons were designed to minimize the amount of intronic sequence and to avoid repetitive elements. PCR primers were designed using PrimerSelect (DNASTAR) and purchased from BioCorp. Primer sequences, amplicon sizes, and amplification conditions are given in Tables 1 and 2. Genomic DNA was isolated from blood samples using conventional methods. Samples were amplified using TaqDNA polymerase (QIAGEN) on a PE 9700 PCR thermocycler (PerkinElmer). Amplification conditions were determined by testing several annealing temperatures, and by addition of Q solution (QIAGEN) for problematic amplicons on control genomic DNA samples. All amplified fragments were tested by agarose gel electrophoresis.

Denaturing HPLC and sequence analysis. PCR fragments were optimized for melting temperature on a model 3500 HT WAVE denaturing HPLC (dHPLC) (Transgenomic) with Wavemaker software, version 4.1.44. After PCR and dHPLC optimization, PCR fragments from DNA samples were amplified using the optimized conditions and the fragments were then tested on agarose gels. Amplified fragments were pooled four times, denatured at $95^{\circ} \mathrm{C}$ in a heating block for $5 \mathrm{~min}$, and renatured slowly by cooling the block to $25^{\circ} \mathrm{C}$ over the course of $1 \mathrm{~h}$. The pooled PCR fragments were run on the dHPLC apparatus at two different melting temperatures. The elution profiles of each sample pool were compared, and samples from one to three pools showing variant elution profiles were selected for sequence determination at the Genome Quebec Innovation Centre Sequencing Facility (Montréal, Québec, Canada). Sequencing reactions were performed on an ABI Prism 3700 sequencing apparatus using manufacturer's recommended conditions. Sequence traces were aligned using SeqManII (DNASTAR). Base pair variants were identified and annotated. Publicly available predicted single-nucleotide polymorphisms (SNPs) (from NCBI dbSNP, version 132) were identified, and those found in the sequence alignment were noted.

Genotyping of patient samples. Genotyping was performed by direct sequencing, allele-specific oligonucleotide (ASO) hybridization, or restriction fragment length polymorphism (RFLP) assay. Genotypes were scored manually or generated using Mutation Surveyor (SoftGenetics). For each ASO assay, two oligonucleotides were designed to differentiate wild-type from the mutant alleles. The ASO assays were done as described previously (Bourgeois and Labuda, 2004). Briefly, each oligonucleotide was end-labeled with $\left[\gamma_{-}{ }^{32} \mathrm{P}\right] \mathrm{dATP}$ using T4 kinase in a $25 \mu \mathrm{l}$ of total reaction volume. Probes were hybridized to nylon membranes to which was affixed the desired PCR amplified fragments, washed, and exposed to $\mathrm{x}$-ray film. Films were scored and the genotypes for all successfully amplified samples were determined. The p.G257R variant was genotyped using an MspI RFLP assay. The 465 bp fragment from amplicon 3B (Table 1) was digested with MspI restriction en-
B

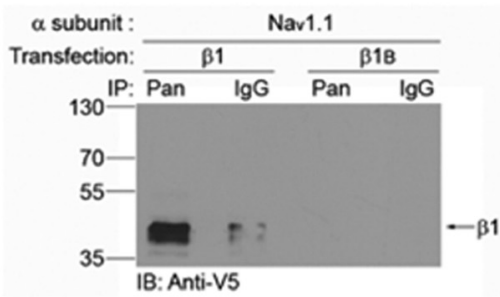

D

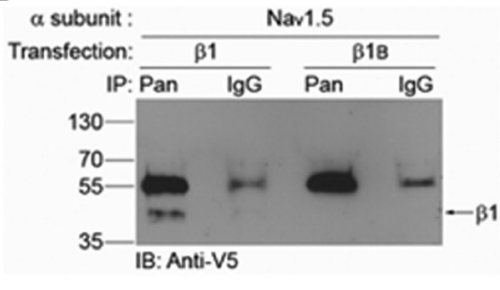

Figure 4. Cell surface expression and association of VGSC $\alpha$ - and $\beta 1$ - or $\beta 1 B$-subunits. $A, \beta 1 B$ is located at the cell surface in the presence of $\mathrm{Na}_{v} 1.5$. Top panel, Cell surface biotinylation of cell lines stably expressing $\mathrm{Na}_{v} 1.1, \mathrm{Na}_{v} 1.3$, or $\mathrm{Na}_{v} 1.5$ cotransfected with $\beta 1 B V$ ( $\beta 1 B-1.1, \beta 1 B-1.3$, and $\beta 1 B-1.5$ lanes, respectively) analyzed by Western blot and probed with anti-V5. Surface (1) samples probed with anti- $\mathrm{Na}^{+} / \mathrm{K}^{+}$ATPase $\beta 1$ showed equal loading of surface proteins. Molecular weight (MW) markers are VGSC antibody for immunoprecipitation ( $\beta 1$ Pan or $\beta 1 B$ Pan) followed by anti-V5 to probe the Western blot. Immunoprecipitation lysates of $\beta 1 \mathrm{~B}$-expressing cells used in $\boldsymbol{B}-\boldsymbol{D}$ to confirm the presence of $\beta 1 \mathrm{~B}$ : $\mathrm{Na} \mathrm{a}_{\mathrm{v}} 1.1+\beta 1 \mathrm{~B}$ line (1.1, left panel), $\mathrm{Na}_{\mathrm{v}} 1.3$ plus $\beta 1 \mathrm{~B}$ line (1.3, middle panel), $\mathrm{Na}_{\mathrm{v}} 1.5$ plus $\beta 1 \mathrm{~B}$ line (1.5, right panel). All blots are representative of triplicate repeats. $\mathrm{MW}$ markers are given in kilodaltons. The arrows indicate immunoreactive $\beta 1$ or $\beta 1 \mathrm{~B}$ bands.

zyme (New England Biolabs), and the products were separated on a $1.5 \%$ agarose gel. The $257 \mathrm{Gly}$ allele yields digested products of 49,87 , 90 , and $239 \mathrm{bp}$ in size, whereas the 257Arg allele yields fragments of 49,87 , and 329 bp in size.

Statistical analyses. Continuous data, $n<200$, were tested for normality using the Kolmogorov-Smirnov test. All continuous data were tested for homogeneity of variances using the Levene test. These data were normally distributed, and thus group means were compared using twotailed Student's $t$ test or ANOVA. If homogeneity of variance existed, Tukey's test was selected as the post hoc test; otherwise, Tamhane's T2 was used. Statistical significance was set at $p<0.05$. SPSS was used for all determinations of statistical significance. The bar graphs were obtained using SPSS, Origin 7 (OriginLab Corporation), or Prism 5 (GraphPad).

\section{Results}

Expression patterns of $\beta 1$ and $\beta 1 B$ in human brain are developmentally regulated

We demonstrated previously that $\beta 1$ and $\beta 1 \mathrm{~B}$ mRNA have complementary expression patterns in rat brain (Kazen-Gillespie et 

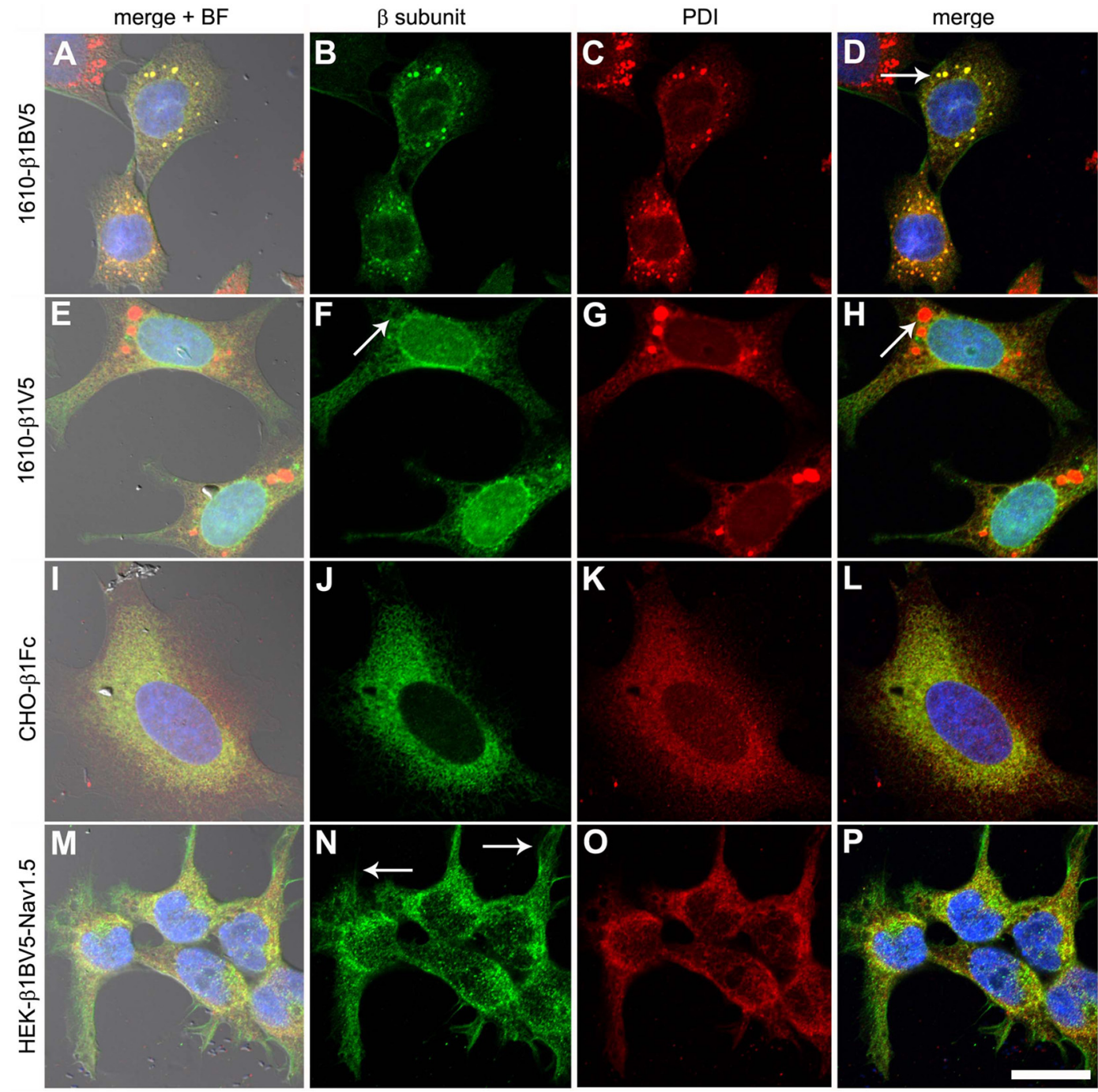

Figure 5. $\quad \beta 1 \mathrm{~B}$ is detected in the ER in the absence of $\mathrm{Na}_{\mathrm{v}} 1.5$, and at the cell surface when coexpressed with $\mathrm{Na}_{\mathrm{v}} 1.5$. Cells expressing $\beta 1 \mathrm{~V} 5, \beta 1 \mathrm{BV} 5, \beta 1 \mathrm{Fc}$, or $\beta 1 \mathrm{BV} 5$ plus Nav1.5 were labeled with anti-PDI to mark the ER, and anti-V5 or anti-Fc antibodies to label $\beta$-subunits. Merged images are presented with and without bright-field (BF) illumination to clearly show both fluorescent signal as well as identify cell borders. $\boldsymbol{A}-\boldsymbol{D}, 1610-\beta 1 B V 5$ cells display strong anti-V5 signal coincident with anti-PDI signal ( $\boldsymbol{D}$, arrow). $\boldsymbol{E}-\boldsymbol{H}, 1610-\beta 1 V 5$ cells display a diffuse anti-V5 signal but lack the ER localization seen in 1610- $\beta 1 B$ cells, consistent with plasma membrane expression of $\beta 1(\boldsymbol{F}, \boldsymbol{H}$, arrows). $\boldsymbol{I}-\boldsymbol{L}, \mathbf{C H O}-\beta 1 F \mathbf{F}$ cells display strong overlap of anti-Fc and anti-PDI immunofluorescence, consistent with the nature of $\beta 1 \mathrm{Fc}$ as a secreted protein. $\boldsymbol{M - P}$, HEK- $\beta 1 \mathrm{BV} 5$-Nav1.5 cells display diffuse anti-V5 signal that extends beyond the ER, including expression within filipodial structures at the cell border ( $N$, arrows). Scale bar, $20 \mu \mathrm{m}$.

al., 2000). $\beta 1 \mathrm{~B}$ is expressed predominantly during embryonic rat brain development, with levels decreasing after birth. In contrast, $\beta 1$ expression is low in embryonic rat brain, but becomes dominant over $\beta 1 \mathrm{~B}$ in postnatal brain. To determine whether this developmental expression pattern is conserved in humans, we performed RT-PCR using primers specific for $\beta 1$ or $\beta 1 \mathrm{~B}$ and human frontal lobe total RNA as template. Samples were obtained from both human embryonic brain (22 and 36 weeks of gestation) and human postnatal brain (age range, $9-56$ years). In addition, we obtained occipital lobe total RNA from the postnatal subjects. RNA from Scnlb-null mouse brain was used as a negative control. At the earliest time point assayed, 22 weeks of gestation, both variants were detected, although higher levels of $\beta 1 \mathrm{~B}$ were detected compared with $\beta 1$. As development progressed, the level of $\beta 1 \mathrm{~B}$ appeared to remain relatively constant while the level of $\beta 1$ increased (Fig. 1A). To quantify these results, we prepared cDNA from each RNA sample and performed quantitative PCR using the TaqMan assay. Ratios of $\beta 1$ to $\beta 1 \mathrm{~B}$ were compared using the $2^{-\Delta \mathrm{CT}}$ method. At 22 weeks of gestation, $\beta 1: \beta 1 \mathrm{~B}=0.08$ (mean $\left.2^{-\Delta \mathrm{CT}} \pm \mathrm{SD}, 0.08 \pm 0.15\right)$. At 36 weeks of gestation, $\beta 1 \mathrm{~B}$ and $\beta 1$ levels were similar $(\beta 1: \beta 1 \mathrm{~B}, 1.22 \pm 0.91)$. After birth, levels of $\beta 1$ transcript were $\sim 18$-fold higher than $\beta 1 \mathrm{~B}$ $(\beta 1: \beta 1 \mathrm{~B}, 17.84 \pm 3.45$; Fig. $1 B)$. We found no significant differences between results obtained from the various postnatal subjects (data not shown), and thus these values were pooled.

\section{VGSC $\beta 1 B$ is a secreted protein}

The topology of $\beta 1$ is well understood (Isom et al., 1992); however, less is known about $\beta 1 \mathrm{~B}$. In silico analyses of the predicted amino acid sequences of human $\beta 1$ and $\beta 1 \mathrm{~B}$ were performed using the Goldman Engelman Steitz hydrophobicity scale as described in Materials and Methods. In contrast to $\beta 1$ (Isom et al., 1992 ), a hydrophobic transmembrane domain was not predicted for $\beta 1 \mathrm{~B}$ (Fig. $2 A$ ). The predicted $\beta 1$ and $\beta 1 \mathrm{~B}$ amino acid sequences from rat and mouse were analyzed similarly for hydrophobicity. In contrast to predicted amino acid sequences for $\beta 1$ from these species, which are highly conserved and contain predicted hydrophobic domains (Fig. $2 B, C$ ), very little similarity 
was found in the $\mathrm{C}$-terminal region unique to $\beta 1 \mathrm{~B}$, suggesting that the sequence of this domain is species specific (Fig. 2D). Importantly, none of these unique $\beta 1 \mathrm{~B}$ sequences contained a predicted transmembrane domain, suggesting that $\beta 1 \mathrm{~B}$ may be a secreted protein (Fig. 2E).

To investigate whether $\beta 1 \mathrm{~B}$ is indeed a secreted protein, we stably transfected Chinese hamster lung 1610 fibroblasts with a V5-His epitope-tagged human $\beta 1 \mathrm{~B}$ cDNA construct (1610- $\beta 1 B V 5)$. Protein expression at the cell surface was assessed by surface biotinylation, probing the final Western blot with anti-V5 antibody. 1610 cells stably expressing $\beta 1 \mathrm{~V} 5$ (1610- $\beta 1 \mathrm{~V} 5)$ were used as a positive control (Patino et al., 2009), and as expected, $\beta 1$ V 5 was detected at the cell surface (Fig. $3 A$ ). In contrast, $\beta 1 \mathrm{BV} 5$ was not detected at the cell surface despite abundant levels of $\beta 1 \mathrm{BV} 5$ protein in the whole-cell lysate sample (Fig. 3A). We next assayed conditioned media by Western blot to test for the presence of $\beta 1 \mathrm{~B}$. Anti-V5-immunoreactive bands were present in conditioned media from $1610-\beta 1 B V 5$ cells, while, as expected, no bands were detected in media from $1610-\beta 1 \mathrm{~V} 5$ cells despite high levels of protein present on the Ponceau redstained blot (Fig. 3B).

The migration of $\beta 1 \mathrm{~B}$ by SDS-PAGE was variable, over a size range of $\sim 26 \mathrm{kDa}$ (the predicted molecular weight of nonglycosylated $\beta 1 \mathrm{~B}$ ) to 45 $\mathrm{kDa}$, with the majority of experimental results showing the $\sim 45$ $\mathrm{kDa}$ band. Interestingly, the same clonal line of $1610-\beta 1 \mathrm{BV} 5$ cells yielded bands of different sizes in different experiments. We hypothesized that these bands might represent different glycosylation states of $\beta 1 \mathrm{~B}$ and that enzymes present in the culture medium or experimental solutions might result in artifactual deglycosylation of this protein. To test this, whole-cell lysates of $1610-\beta 1 B V 5$ cells were treated with PNGase F and samples were then analyzed by Western blot. PNGase F treatment resulted in collapse of the $\beta 1 \mathrm{~B}$-immunoreactive band from $\sim 45$ to $\sim 26 \mathrm{kDa}$ (Fig. $3 \mathrm{C}$ ), suggesting that the various immunoreactive $\beta 1 \mathrm{~B}$ bands identified in the conditioned media represent different glycosylation states. Together, these data suggest that both $\beta 1$ and $\beta 1 \mathrm{~B}$ are glycoproteins. Furthermore, they suggest that, while $\beta 1$ has transmembrane topology, $\beta 1 \mathrm{~B}$ is a secreted protein that may be critical during embryonic brain development.

\section{Differential effects of VGSC $\alpha$-subunits on $\beta 1 B$ cell surface expression}

The experiments in Figure 3 demonstrate that $\beta 1 \mathrm{~B}$ is secreted from cells that do not express VGSCs. To test whether the presence of a VGSC $\alpha$-subunit may result in retention of $\beta 1 \mathrm{~B}$ at the cell surface, we studied cell lines coexpressing human $\beta 1 B V 5$ with human VGSC $\alpha$-subunits. Because SCN1B mutations affecting the region specific to $\beta 1 \mathrm{~B}$ are associated with cardiac arrhythmia (Watanabe et al., 2008) and epilepsy (shown here), we tested the effects of human $\mathrm{Na}_{\mathrm{v}} 1.1$, a common target of genetically determined epilepsy (Meisler et al., 2010), and human $\mathrm{Na}_{\mathrm{v}} 1.5$, the
VGSC $\alpha$-subunit most prevalent in heart and a target of inherited arrhythmia (Catterall et al., 2005; Remme et al., 2008; Ruan et al., 2009). In addition, because $\beta 1 \mathrm{~B}$ is mainly expressed during embryonic brain development (Fig. 1), we tested the effects of human $\mathrm{Na}_{\mathrm{v}} 1.3$, the predominant VGSC expressed in embryonic brain (Catterall et al., 2005). For unknown reasons, we were unable to establish stable $\beta 1$ V5- or $\beta 1 B V 5$-expressing cell lines using HEKhNa 1.1 cells (Patino et al., 2009). Thus, all experiments with this cell line were performed following transient transfection of $\beta 1 \mathrm{~V} 5$ or $\beta 1 \mathrm{BV} 5 \mathrm{cDNA}$. We were able to establish stable $\beta$-subunit-expressing lines using HEK cells stably transfected with human $\mathrm{Na}_{\mathrm{v}} 1.5\left(\mathrm{HEKhNa}_{\mathrm{v}} 1.5\right)$. Finally, Chinese hamster ovary fibroblasts stably expressing human $\mathrm{Na}_{\mathrm{v}} 1.3\left(\mathrm{CHOhNa}_{\mathrm{v}} 1.3\right)$ (Meadows et al., 2002a) were stably transfected with human $\beta 1$ or $\beta 1 \mathrm{~B}$ cDNAs. Similar to 1610 cells expressing no VGSC $\alpha$-subunits, $\beta 1 \mathrm{~B}$ was not detected at the surface of cells coexpressing $\mathrm{Na}_{\mathrm{v}} 1.1$ or $\mathrm{Na}_{\mathrm{v}} 1.3$ (Fig. $4 A$ ), suggesting that $\beta 1 \mathrm{~B}$ is secreted despite the presence of these channels. In contrast, cell surface $\beta 1 \mathrm{~B}$ expression was detected in biotinylated samples from cells coexpressing $\mathrm{Na}_{\mathrm{v}} 1.5$ and $\beta 1 \mathrm{~B}$ (Fig. $4 A$ ), suggesting that $\beta 1 \mathrm{~B}$ may be selectively retained at the cell surface by this channel and consistent with previous results showing modulation of $\mathrm{Na}_{\mathrm{v}} 1.5$ mediated $\mathrm{Na}^{+}$current by $\beta 1 \mathrm{~B}$ (Watanabe et al., 2008).

\section{Effects of $\beta 1$ and $\beta 1 B$ on VGSC $\alpha$-subunit cell surface expression}

$\beta 1$ associates with multiple VGSC $\alpha$-subunits and increases their functional expression. For example, $\beta 1$ associates with $\mathrm{Na}_{\mathrm{v}} 1.2$ and this association is functionally detected by increased $\mathrm{Na}^{+}$ 
current density and by increased cell surface $\left[{ }^{3} \mathrm{H}\right]$ STX binding (Isom et al., 1995; McEwen et al., 2004). Rat $\beta 1 \mathrm{~B}$ increases the cell surface expression of rat $\mathrm{Na}_{\mathrm{v}} 1.2$ in transfected cells, with subtle changes in current activation and inactivation, suggesting that these subunits functionally associate (Kazen-Gillespie et al., 2000). Similarly, human $\beta 1 \mathrm{~B}$ coexpression increases $\mathrm{Na}^{+}$current density generated by human $\mathrm{Na}_{\mathrm{v}} 1.5$ (Watanabe et al., 2008), again suggesting functional association. In the following set of experiments, we asked whether specific $\alpha$ - and $\beta 1$ - or $\beta 1 \mathrm{~B}$ subunits associate and whether coexpression of $\beta 1$ or $\beta 1 \mathrm{~B}$ results in increased $\alpha$-subunit cell surface expression.

We used coimmunoprecipitation assays to examine whether human $\beta 1 \mathrm{~B}$ associates with human $\mathrm{Na}_{\mathrm{v}} 1.1$, human $\mathrm{Na}_{\mathrm{v}} 1.3$, or human $\mathrm{Na}_{\mathrm{v}}$ 1.5. In these experiments, anti-pan-VGSC antibody was used for the immunoprecipitation step from Triton X-100solubilized whole-cell lysates, and Western blots were probed with anti-V5 to detect associated $\beta$-subunits. $\beta 1$ coprecipitated with $\mathrm{Na}_{\mathrm{v}} 1.1$ (Fig. $4 B$ ), $\mathrm{Na}_{\mathrm{v}} 1.3$ (Fig. $4 C$ ), and $\mathrm{Na}_{\mathrm{v}} 1.5$ (Fig. $4 D$ ). In contrast, $\beta 1 \mathrm{~B}$ association was not detected with any $\alpha$-subunit (Fig. $4 B-D$ ). Western blots of whole-cell lysates from each cell line coexpressing $\alpha$ - and $\beta 1 \mathrm{BV} 5$-subunits demonstrated the presence of $\beta 1 \mathrm{~B}$ in all three (Fig. $4 E$ ). Lack of association between $\mathrm{Na}_{\mathrm{v}} 1.5$ and $\beta 1 \mathrm{~B}$ in the coimmunoprecipitation assay contrasts with our result above, showing cell surface retention of $\beta 1 \mathrm{~B}$ in the presence of $\mathrm{Na}_{\mathrm{v}} 1.5$, and with those of others (Watanabe et al., 2009). Possible explanations for this discrepancy may be that the interaction between $\beta 1 \mathrm{~B}$ and $\mathrm{Na}_{\mathrm{v}} 1.5$ is disrupted by detergent solubilization or that $\mathrm{Na}_{\mathrm{v}} 1.5$ and $\beta 1 \mathrm{~B}$ associate transiently or with low affinity such that their interaction cannot be captured biochemically.

We performed immunofluorescent labeling of cells transfected with $\beta 1 \mathrm{BV} 5, \beta 1 \mathrm{~V} 5, \beta 1 \mathrm{Fc}$, or $\beta 1 \mathrm{BV} 5$ plus $\mathrm{Na}_{\mathrm{v}} 1.5$ to assess the subcellular localization of each of these $\beta$-subunits (Fig. 5). Anti-V5 staining of $\beta 1 \mathrm{BV} 5$ cells demonstrates $\beta 1 \mathrm{~B}$ ER localization, as indicated by anti-V5 immune signal coincident with that for the ER marker PDI (Fig. $5 A-D$ ). In contrast, $\beta 1 \mathrm{~V} 5$, which has been shown previously to be a transmembrane protein (Isom et al., 1992), is more evenly distributed in all cell areas, including the cell surface (Fig. $5 E-H$ ). As a control for the subcellular distribution of a known secreted protein, we performed a similar labeling experiment using $\beta 1 \mathrm{Fc}$, which we have shown previously to be a secreted protein (McEwen and Isom, 2004) (Fig. 5I-L). This engineered, secreted form of $\beta 1$ displays strong overlapping fluorescent signals with that of PDI, similar to the overlap observed in $\beta 1 \mathrm{BV} 5$ cells. Finally, we stained cells coexpressing $\beta 1 \mathrm{BV} 5$ plus $\mathrm{Na}_{\mathrm{v}} 1.5$ subunits with anti-V5 and anti-PDI to visualize $\beta 1 \mathrm{~B}$ in the presence of a VGSC $\alpha$-subunit (Fig. $5 M-P$ ). In addition to its localization in intracellular organelles, and consistent with surface biotinylation assays (Fig. $4 A$ ), $\beta 1 \mathrm{BV} 5$ staining was detectable at the cell surface (Fig. $5 \mathrm{~N}$, arrows), particularly in filopodia-like extensions at the cell borders. Together, these immunofluorescence results suggest that $\beta 1 \mathrm{~B}$ is a secreted protein. Furthermore, they confirm that the subcellular distribution of $\beta 1 \mathrm{~B}$ is altered when coexpressed with $\mathrm{Na}_{\mathrm{v}} 1.5$.

$\left[{ }^{3} \mathrm{H}\right] \mathrm{STX}$ binding to intact cells was used to assay $\mathrm{Na}_{\mathrm{v}} 1.3$ cell surface expression in the presence and absence of $\beta$-subunits. Because STX is membrane impermeant, binding to intact cells measures only cell surface and not intracellular channels (McEwen et al., 2004, 2009). As expected, $\beta 1$ significantly increased cell surface $\left[{ }^{3} \mathrm{H}\right]$ STX binding compared with $\mathrm{Na}_{\mathrm{v}} 1.3$ alone $\left(\mathrm{Na}_{\mathrm{v}} 1.3\right.$ plus $\beta 1,8.93 \pm 0.72 \mathrm{fmol} / \mathrm{mg}$, vs Na 1.3 alone, $5.53 \pm 0.65 \mathrm{fmol} / \mathrm{mg}$; $n=9$ for each subunit combination; $p<0.001$ ). In contrast, $\beta 1 \mathrm{~B}$ did not significantly increase cell surface $\left[{ }^{3} \mathrm{H}\right]$ STX binding com-
Table 3. Electrophysiological analysis of $\mathrm{Na}^{+}$currents

\begin{tabular}{|c|c|c|c|}
\hline & $\mathrm{Na}_{\mathrm{v}} 1.3$ & $\mathrm{Na}_{\mathrm{v}} 1.3 \beta 1$ & $\mathrm{Na}_{\mathrm{v}} 1.3 \beta 1 \mathrm{~B}$ \\
\hline \multicolumn{4}{|l|}{$\begin{array}{c}\text { Voltage dependence } \\
\text { of activation }\end{array}$} \\
\hline$V_{1 / 2}(\mathrm{mV})$ & $-15.76 \pm 0.98$ & $-22.59 \pm 1.22^{*}$ & $-18.15 \pm 0.91$ \\
\hline$k$ & $5.21 \pm 0.21$ & $4.88 \pm 0.26$ & $4.80 \pm 0.84$ \\
\hline$n$ & 21 & 15 & 23 \\
\hline \multicolumn{4}{|l|}{$\begin{array}{l}\text { Voltage dependence } \\
\text { of inactivation }\end{array}$} \\
\hline$V_{1 / 2}(\mathrm{mV})$ & $-51.77 \pm 0.63$ & $-63.97 \pm 1.40^{*}$ & $-51.92 \pm 0.85$ \\
\hline$k$ & $-5.47 \pm 0.13$ & $-5.96 \pm 0.31$ & $-5.43 \pm 0.17$ \\
\hline$c$ & $0.02 \pm 0.001$ & $0.02 \pm 0.002$ & $0.02 \pm 0.003$ \\
\hline$n$ & 21 & 15 & 23 \\
\hline \multicolumn{4}{|l|}{ Kinetics of inactivation } \\
\hline$\tau_{\text {slow }}(\mathrm{ms})$ & $4.00 \pm 0.31$ & $3.58 \pm 0.31$ & $3.92 \pm 0.32$ \\
\hline Amplitude $_{\text {slow }}(\%)$ & $12.27 \pm 0.87$ & $8.96 \pm 0.95^{* *}$ & $9.51 \pm 0.68^{* *}$ \\
\hline$\tau_{\text {fast }}(\mathrm{ms})$ & $0.65 \pm 0.03$ & $0.49 \pm 0.04^{* * *}$ & $0.56 \pm 0.02^{* * * *}$ \\
\hline Amplitude $_{\text {fast }}(\%)$ & $76.41 \pm 0.91$ & $78.47 \pm 0.88$ & $79.14 \pm 0.99$ \\
\hline C & $3.30 \pm 0.25$ & $2.42 \pm 0.47$ & $3.14 \pm 0.46$ \\
\hline$n$ & 20 & 14 & 20 \\
\hline \multicolumn{4}{|l|}{ Kinetics of recovery } \\
\hline$\tau(\mathrm{ms})$ & $1.86 \pm 0.04$ & $2.61 \pm 0.16^{*}$ & $1.63 \pm 0.06^{*}$ \\
\hline$n$ & 17 & 12 & 22 \\
\hline
\end{tabular}
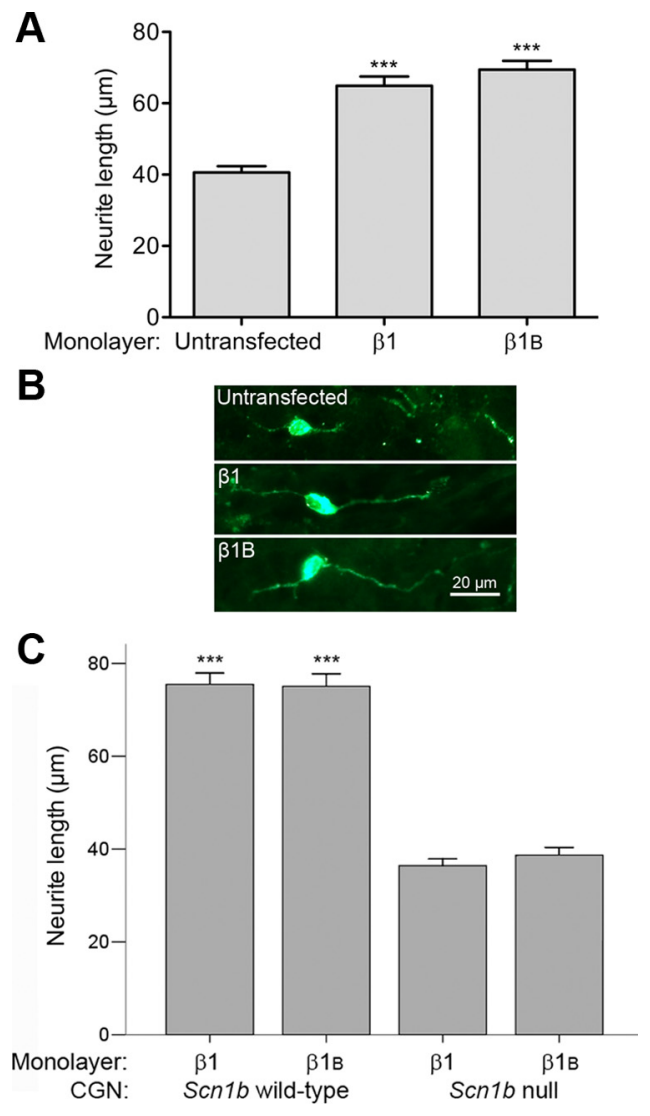

Figure 7. $\beta 1 \mathrm{~B}$ stimulates neurite outgrowth of CGNs. A, Neurite lengths of CGNs isolated from wild-type mice grown on 1610 cells (Untransfected) or 1610 cells stably expressing $\beta 1 V 5$ $(\beta 1)$ or $\beta 1$ BV5 ( $\beta 1 B)$ measured as described in Materials and Methods. Significance, ${ }^{* * *} p<$ 0.001. $\boldsymbol{B}$, Examples of increased neurite length. CGNs grown on CHL monolayers were fixed in $4 \%$ paraformaldehyde for 10 min and then processed for immunocytochemistry using an antiGAP43 antibody (1:500; Millipore), as described previously (Davis et al., 2004). C, Neurite lengths of CGNs from wild-type and Scn 1b-null mice grown on 1610 cells stably expressing $\beta 1 V 5$ or $\beta 1 B V 5$. Significance, ${ }^{* * *} p<0.001$. All data are presented as mean \pm SEM. 
pared with cells expressing only $\mathrm{Na}_{\mathrm{v}} 1.3$ $\left(\mathrm{Na}_{\mathrm{v}} 1.3\right.$ plus $\left.\beta 1 \mathrm{~B}, 5.90 \pm 0.92 \mathrm{fmol} / \mathrm{mg}\right)$.

\section{Functional modulation of $\mathrm{Na}^{+}$current by $\beta 1 \mathrm{~B}$}

We showed previously that rat $\beta 1 \mathrm{~B}$ exerted subtle but significant effects on rat $\mathrm{Na}_{\mathrm{v}} 1.2$-generated $\mathrm{Na}^{+}$current activation and inactivation in transfected cells (Kazen-Gillespie et al., 2000). To examine whether coexpression of $\beta 1$ or $\beta 1 \mathrm{~B}$ modulated $\mathrm{Na}_{\mathrm{v}} 1.3$-generated $\mathrm{Na}^{+}$current, we performed whole-cell patch-clamp recordings on $\mathrm{CHO} \mathrm{hNa}_{\mathrm{v}} 1.3$ cells in the presence and absence of stable expression of human $\beta 1$ or $\beta 1 \mathrm{~B}$. Consistent with our coimmunoprecipitation and $\left[{ }^{3} \mathrm{H}\right] \mathrm{STX}$ binding results, $\beta 1$ coexpression had significant effects on $\mathrm{Na}^{+}$current. $\beta 1$ significantly increased $\mathrm{Na}^{+}$current density at test potentials over a range from -45 to 0 $\mathrm{mV}$ (Fig. $6 A$ ) and shifted the voltage dependence of activation by $\sim 6 \mathrm{mV}$ and the voltage dependence of inactivation by $\sim 12 \mathrm{mV}$, both in the hyperpolarizing direction. In contrast, $\beta 1 \mathrm{~B}$ produced more subtle changes. $\beta 1 \mathrm{~B}$ coexpression resulted in a minor increase in $\mathrm{Na}^{+}$current density and a small hyperpolarizing shift in the voltage dependence of current activation; however, these changes were not statistically significant (Fig. $6 A, B$ ). $\beta 1 \mathrm{~B}$ had no measurable effect on the voltage dependence of current inactivation (Fig. $6 C$ ). Both $\beta 1$ and $\beta 1 \mathrm{~B}$ modulated the kinetics of inactivation and recovery from inactivation (Fig. $6 D$, Table 3). $\beta 1$ and $\beta 1 \mathrm{~B}$ decreased the time constant, $\tau$, of fast inactivation, although $\beta 1$ had a more significant effect than $\beta 1 \mathrm{~B}$ (Table 3). Interestingly, $\beta 1$ and $\beta 1 \mathrm{~B}$ had opposite effects on the kinetics of recovery from inactivation: $\beta 1$ coexpression increased, while $\beta 1 \mathrm{~B}$ expression decreased, $\tau$ compared with $\alpha$ alone. In summary, coexpression of $\mathrm{Na}_{\mathrm{v}} 1.3$ plus $\beta 1$ resulted in increased $\mathrm{Na}^{+}$current density, decreased channel availability, acceleration of the development of fast inactivation, and deceleration of the rate of recovery from inactivation compared with $\mathrm{Na}_{\mathrm{v}} 1.3$ alone. In contrast, coexpression of $\mathrm{Na}_{\mathrm{v}} 1.3$ plus $\beta 1 \mathrm{~B}$ accelerated the development of fast inactivation and increased the rate of recovery from inactivation compared with $\mathrm{Na}_{\mathrm{v}} 1.3$ alone. These results suggest that, even though secreted, $\beta 1 \mathrm{~B}$ may exert subtle effects on $\mathrm{Na}^{+}$current in brain neurons. Furthermore, these effects may be autocrine or paracrine.

\section{$\beta 1 B$ stimulates neurite outgrowth in CGNs through $\beta 1$ adhesion}

VGSC $\beta$-subunits contain a single extracellular Ig domain and function as CAMs (Malhotra et al., 2000, 2002; McEwen and Isom, 2004). $\beta 1$ promotes CGN neurite outgrowth in vitro and in vivo through trans homophilic cell-adhesive interactions (Davis et al., 2004; Brackenbury et al., 2008a, 2010). Because $\beta 1$ and $\beta 1 \mathrm{~B}$ contain identical Ig loop domains, we hypothesized that $\beta 1 \mathrm{~B}$ may function as a secreted CAM to promote neurite outgrowth. Previous results using an engineered soluble $\beta 1$ extracellular domain to promote CGN neurite outgrowth and to bind to other CAMs support this idea (Davis et al., 2004; McEwen and Isom, 2004). To test this hypothesis, we investigated the ability of $\beta 1 \mathrm{~B}$ to promote neurite outgrowth of CGNs. CGNs were isolated from P14 C57BL/6 mice and plated on monolayers of untransfected 1610 cells (as a negative control), 1610- $\beta 1 \mathrm{~V} 5$ cells (as a positive control), or $1610-\beta 1$ BV5 cells, as described in Materials and Methods. After $24 \mathrm{~h}$ of incubation, cells were fixed and immunostained with anti-GAP43, and the length of the longest neurite was measured. Consistent with previous results (Davis et al., 2004; Brackenbury et al., 2008a), the mean neurite length of CGNs plated on $1610-\beta 1 \mathrm{~V} 5$ cells (mean \pm SE, $64.88 \pm 2.63 \mu \mathrm{m}$ ) was significantly greater than CGNs plated on 1610 cells $(40.64 \pm 1.70 \mu \mathrm{m})$. Importantly, the mean neurite length of CGNs plated on 1610$\beta 1 \mathrm{BV} 5$ cells $(69.43 \pm 2.46 \mu \mathrm{m})$ was also statistically greater than CGNs plated on 1610 cells, and not significantly different from cells plated on 1610- $\beta 1 \mathrm{~V} 5$ cells $(n=300$ for each group; $p<$ 0.001; Fig. 7A). Examples of CGN neurite length are shown in Figure $7 \mathrm{~B}$. Thus, similar to $\beta 1, \beta 1 \mathrm{~B}$ functions as a CAM to promote neurite outgrowth. In contrast to $\beta 1$, however, we propose that $\beta 1 \mathrm{~B}$ functions as a secreted rather than as a transmembrane CAM.

The neurite outgrowth-promoting activity of $\beta 1$ is abolished in CGNs isolated from Scn1b-null mice (Davis et al., 2004), demonstrating that trans homophilic $\beta 1-\beta 1$ interactions are required. To test whether a similar requirement of $\beta 1$ expression on the neuron exists for $\beta 1 \mathrm{~B}$ signaling, we compared neurite outgrowth of CGNs isolated from Scn1b-null mice versus wild-type controls plated on $\beta 1 \mathrm{~B}$-secreting monolayers. In agreement with our previous studies (Davis et al., 2004), the mean neurite length of wild-type CGNs plated on 1610- $\beta 1 \mathrm{~V} 5$ cells $(75.46 \pm 2.44 \mu \mathrm{m})$ was statistically greater than for Scn1b-null CGNs (36.42 \pm 1.45 $\mu \mathrm{m})$. Similarly, the mean neurite length of wild-type CGNs plated on $1610-\beta 1 B V 5$ cells $(75.06 \pm 2.71 \mu \mathrm{m})$ was significantly higher than that of null CGNs $(38.66 \pm 1.69 \mu \mathrm{m} ; n=300$ per condition; $p<0.001$; Fig. $7 C$ ). There was no significant differ- 


\begin{tabular}{|c|c|c|c|c|c|c|c|c|c|c|c|c|c|c|c|c|c|}
\hline \multirow[b]{3}{*}{ Exon } & \multirow[b]{3}{*}{ Position } & \multirow[b]{3}{*}{$\mathrm{dbSNP}$} & \multirow[b]{3}{*}{ Allele 1} & \multirow[b]{3}{*}{ Allele 2} & \multirow[b]{3}{*}{ Impact } & \multirow[b]{3}{*}{ MAF } & \multicolumn{10}{|c|}{ Allelic frequencies by cohort $^{a}$} & \multirow[b]{3}{*}{ Total } \\
\hline & & & & & & & \multicolumn{2}{|c|}{ Epilepsy } & \multicolumn{2}{|c|}{ Migraine } & \multicolumn{2}{|c|}{ Bipolar } & \multicolumn{2}{|c|}{ Tourette } & \multicolumn{2}{|l|}{$\mathrm{ET}$} & \\
\hline & & & & & & & 1 & 2 & 1 & 2 & 1 & 2 & 1 & 2 & 1 & 2 & \\
\hline 1 & chr19:40213619 & None & G & $\mathrm{T}$ & $\begin{array}{l}\text { g. }+15 \text { after the end of } \\
\text { exon } 1\end{array}$ & nd & nd & nd & nd & nd & nd & nd & nd & nd & nd & nd & nd \\
\hline 3 & chr19:40216664 & rs55742440 & $\mathrm{T}$ & $C$ & Leu210Pro & 0.394 & 136 & 94 & 132 & 86 & 83 & 45 & 38 & 32 & 30 & 20 & 696 \\
\hline 3 & chr19:40216676 & None & $\mathrm{G}$ & $A$ & Arg214GIn & 0.005 & 227 & 1 & 219 & 1 & 122 & 2 & 69 & 1 & 50 & 0 & 692 \\
\hline 3 & chr19:40216779 & None & $C$ & $A$ & Ser248Arg & 0.147 & 197 & 33 & 184 & 34 & 109 & 19 & 54 & 16 & 47 & 3 & 696 \\
\hline 3 & chr19:40216784 & None & G & $C$ & Arg250Thr & 0.149 & 198 & 34 & 185 & 33 & 108 & 20 & 54 & 16 & 46 & 4 & 698 \\
\hline 3 & chr19:40216804 & None & $\mathrm{G}$ & $A$ & Gly257Arg & 0.002 & 231 & 1 & 220 & 0 & 128 & 0 & 69 & 1 & 50 & 0 & 700 \\
\hline 5 & chr19:40222354 & rs28365107 & $\mathrm{T}$ & G & $\begin{array}{l}\text { g. }-25 \text { before the start } \\
\text { of } x 05\end{array}$ & nd & nd & nd & nd & nd & nd & nd & nd & nd & nd & nd & nd \\
\hline 5 & chr19:40222365 & rs28365109 & $C$ & $A$ & $\begin{array}{l}\text { g. }-14 \text { before the start } \\
\text { of } x 05\end{array}$ & nd & nd & nd & nd & nd & nd & nd & nd & nd & nd & nd & nd \\
\hline 5 & chr19:40222457 & rs28365106 & $C$ & $\mathrm{~T}$ & $\begin{array}{l}\text { g. + } 6 \text { after the end of } \\
\text { x05 }\end{array}$ & nd & nd & nd & nd & nd & nd & nd & nd & nd & nd & nd & nd \\
\hline 5 & chr19:40222507 & None & G & $\mathrm{T}$ & $\begin{array}{l}\text { g. }+59 \text { after the end of } \\
x 05\end{array}$ & nd & nd & nd & nd & nd & nd & nd & nd & nd & nd & nd & nd \\
\hline 6 & chr19:40222530 & rs28365105 & $C$ & $\mathrm{G}$ & $\begin{array}{l}\text { g. }-18 \text { before the start } \\
\text { of } x 06\end{array}$ & nd & nd & nd & nd & nd & nd & nd & nd & nd & nd & nd & nd \\
\hline 6 & chr19:40222577 & rs2278995 & $\mathrm{T}$ & $C$ & $\begin{array}{l}3^{\prime} \text {-UTR }+42 \text { after the } \\
\text { stop codon }\end{array}$ & 0.135 & 197 & 31 & 179 & 33 & 106 & 20 & 54 & 14 & 47 & 3 & 684 \\
\hline 6 & chr19:40222621 & rs2278996 & $A$ & $C$ & $\begin{array}{l}3^{\prime} \text {-UTR }+86 \text { after the } \\
\text { stop codon }\end{array}$ & nd & nd & nd & nd & nd & nd & nd & nd & nd & nd & nd & nd \\
\hline 6 & chr19:40222718 & None & $C$ & $A$ & $\begin{array}{l}3^{\prime} \text {-UTR }+184 \text { after the } \\
\text { stop codon }\end{array}$ & $\mathrm{nd}$ & nd & nd & nd & nd & nd & nd & nd & nd & nd & nd & nd \\
\hline
\end{tabular}

ET, Essential tremor; nd, not done.

${ }^{a}$ Number of chromosomes from each disease cohort with either allele 1 or 2 .

ence between the mean neurite lengths of wild-type or null CGNs plated on $1610-\beta 1 \mathrm{~V} 5$ cells versus those on $1610-\beta 1 \mathrm{BV} 5$ cells. These data demonstrate that the neurite outgrowth-promoting ability of $\beta 1 \mathrm{~B}$ requires interaction with $\beta 1$-subunits present at the neuronal surface, similar to the mechanism described for $\beta 1$ (Brackenbury et al., 2008a, 2010).

\section{A $S C N 1 B$ mutation affecting $\beta 1 B$ may be a risk factor for idiopathic epilepsy}

Mutations in SCN1B are associated with human disease, including epilepsy and cardiac arrhythmia (Scheffer et al., 2007; Watanabe et al., 2008, 2009; Patino et al., 2009). While one mutation specific to the region encoding $\beta 1 \mathrm{~B}$ is linked to Brugada syndrome (Watanabe et al., 2008), to date all of the SCN1B epilepsy mutations occur in the Ig domain shared by $\beta 1$ and $\beta 1 \mathrm{~B}$ (Patino and Isom, 2010). To test the hypothesis that $S C N 1 B$ mutations specifically affecting $\beta 1 \mathrm{~B}$ and not $\beta 1$ may be associated with epilepsy as well as arrhythmia, all SCN1B exons and intron 3, which is retained in $\beta 1 \mathrm{~B}$ (Fig. 8A) (Kazen-Gillespie et al., 2000; Qin et al., 2003), were amplified by PCR as part of a screening study of 150 genes in 360 unrelated patients with episodic brain disorders (118 with epilepsy, 110 with migraine, 66 with bipolar disorder, 35 with Tourette's syndrome, 25 with essential tremor, 4 with episodic ataxia, 1 with episodic vertigo, and 1 with episodic syncope). A total of $14 S C N 1 B$ variants were identified, of which 5 resulted in amino acid substitutions in the unique region encoding $\beta 1 \mathrm{~B}$ (Table 4). Of these, three had minor allele frequencies $(\mathrm{MAFs})>0.1$ (p.L210P, p.S248R, and p.R250T) and occurred in all cohorts of patients. A variant (p.R214Q) had MAF $=0.005$ but was also present in four of eight cohorts. One variant (p.G257R) was identified in two unrelated probands with idiopathic epilepsy $(\mathrm{MAF}=0.002)$ as a heterozygous mutation (Fig. $8 B)$. One of those probands belonged originally to the Tourette's cohort, but upon further clinical investigation this patient was found to be comorbid for epileptic seizures, suggesting that this variant was associated with an epilepsy phenotype. The patient from pedigree 1 had tonic-clonic seizures starting from 10 years of age. The proband's mother and maternal aunt also had a history of seizures. The patient from pedigree 2 had right temporal seizures with secondary generalized seizures starting at 15 years of age, sometimes preceded by an aura. Seizures were controlled by Tegretol. This patient was also diagnosed with Gilles de la Tourette syndrome, with facial tics and aggressive impulsions. There was no family history of epilepsy in either parent.

To further examine whether the p.G257R variant was associated with Tourette's syndrome, an additional 192 unrelated Tourette's probands were genotyped (data not shown). The variant was not detected in this additional cohort, suggesting that p.G257R is not associated with increased risk of Tourette's syndrome. We screened an additional 187 normal control samples for the portion of intron 3 encoding the unique region of the $\beta 1 \mathrm{~B}$ splice variant. One normal individual was identified with the p.G257R variant, perhaps suggesting incomplete penetrance similar to other $S C N 1 B$ mutations (Scheffer et al., 2007; Watanabe et al., 2008).

To examine the segregation of p.G257R, additional samples from the probands' available family members were genotyped. For pedigree 1, both the proband and her mother carried the mutation and suffered from epilepsy. For pedigree 2, the mutation was inherited from the mother, but there was no reported history of seizures in either parent (Fig. 8C).

\section{$\beta 1 B$ p.G257R is a trafficking-deficient mutation resulting in a functional null allele}

To investigate the mechanism by which $\beta 1 \mathrm{~B}$ p.G257R might contribute to seizures, we stably transfected 1610 cells with V5-Histagged p.G257R cDNA (1610-p.G257RV5). In contrast to wild-type 
A
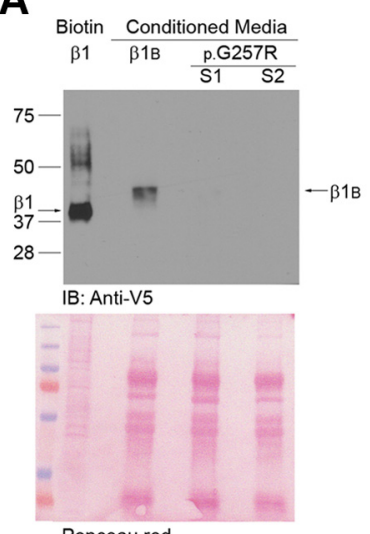

Ponceau red
B

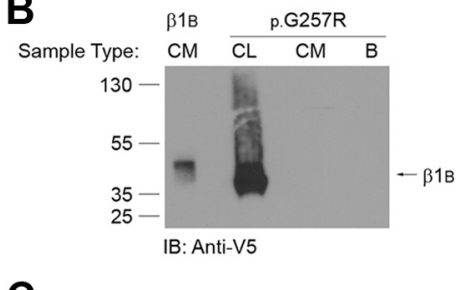

C

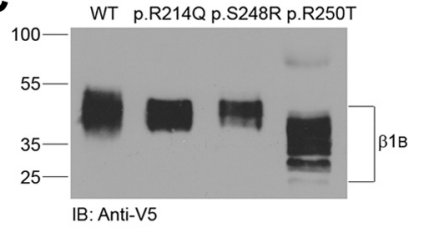

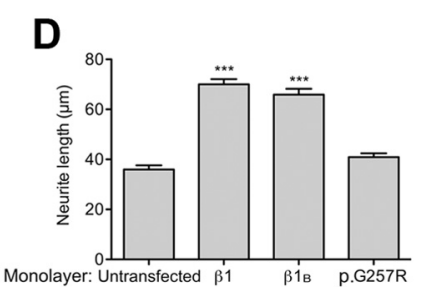

Figure 9. $\beta 1 B$ p.G257R is a trafficking-deficient mutant. $A, \beta 1 B$ but notp.G257R is detected in conditioned media. Top panel, Conditioned media from 1610 cells stably expressing $\beta 1 B V 5$ (Cond. Media $\beta 1$ B) or p.G257RV5 (Cond. Media p.G257R S1 and S2, 2 independent cell clones) were collected, analyzed by Western blot, and probed with anti-V5. A surface biotinylated sample from the 1610- $\beta 1$ V5 clone (Biotin $\beta 1$ ) was used as a positive control. Bottom panel, Ponceau red staining of the nitrocellulose shows protein in all lanes. $\boldsymbol{B}$, p.G257R is retained intracellularly. Western blot analysis of whole-cell lysate (p.G257R CL), surface biotinylated cells (p.G257R B), or conditioned media (p.G257R CM) from the same 1610-p.G257RV5 cell clone. Conditioned media from $1610-\beta 1$ BV 5 cells ( $\beta 1 B C M$ ) shows normal secretion of $\beta 1 B$. C, $\beta 1 B$ polymorphic variants p.R214Q, p.S248R, and p.R250T are secreted into conditioned media similar to wild-type $\beta 1 B$, as indicated. $D$, p.G257R does not stimulate neurite outgrowth. Neurite lengths of CGNs isolated from wild-type mice grown on 1610 cells (Untransfected), 1610 cells stably expressing $\beta 1 \mathrm{~V} 5(\beta 1), 1610$ cells stably expressing $\beta 1$ BV5 $(\beta 1 B)$, or 1610 cells stably expressing p.G257RV5. Data are mean \pm SE. Significance, ${ }^{* * *} p<0.001$. All Western blots are representative of three repeats. Molecular weight markers are given in kilodaltons.

$\beta 1 B V 5$, p.G257RV5 was not detected in conditioned media (Fig. $9 A$ ) despite high levels of expression of the protein in the wholecell lysates (Fig. 9B) and overall protein expression in the Ponceau red-stained blot (Fig. 9A, bottom panel). We used surface biotinylation assays to determine whether p.G257RV5 might be present at the cell surface. As demonstrated in Figure $9 B$, p.G257RV5 was detected in the whole-cell lysate but not in the conditioned media or on the cell surface. From these data, we concluded that p.G257R is a trafficking-deficient mutant. To confirm that the trafficking deficiency of p.G257R is specifically pathogenic, we tested three other SCN1B non-seizure-related polymorphic variants containing amino acid substitutions in $\beta 1 \mathrm{~B}$ found in our cohort of patients: p.R214Q, p.S248R, p.R250T. These variants were present in each disease cohort and hence were not associated with epilepsy (Table 4). To facilitate detection of these proteins, V5-His epitope tags were inserted at their C termini, similar to p.G257RV5. 1610 cells were stably transfected and conditioned media were collected. In contrast to p.G257RV5, all three variants were detected in the conditioned media similar to wild-type $\beta 1 \mathrm{BV} 5$ (Fig. $9 \mathrm{C}$ ). These results suggest that the lack of secretion of p.G257R is a pathogenic change and not a normal variability present in $\beta 1 \mathrm{~B}$ polymorphisms.

Consistent with the observed intracellular retention of p.G257RV5, wild-type CGNs plated on 1610-p.G257RV5 cell

A

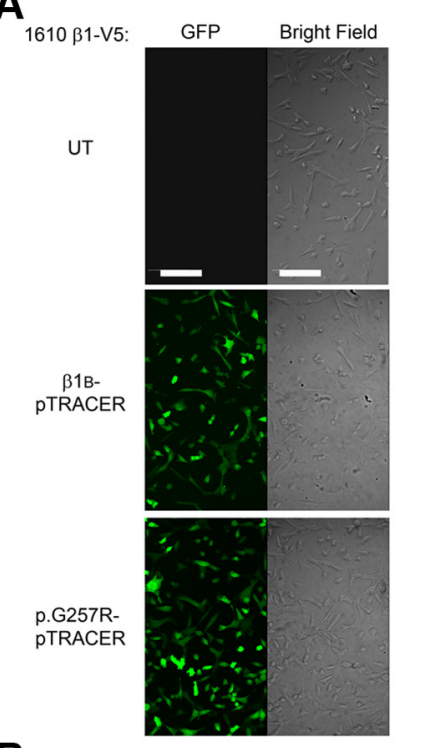

B

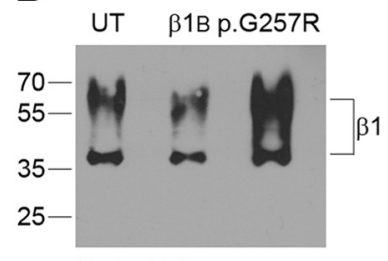

IB: Anti-V5

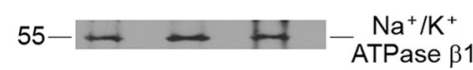

ATPase $\beta 1$

IB: Anti-Na ${ }^{+} / \mathrm{K}^{+}$ATPase $\beta 1$

C
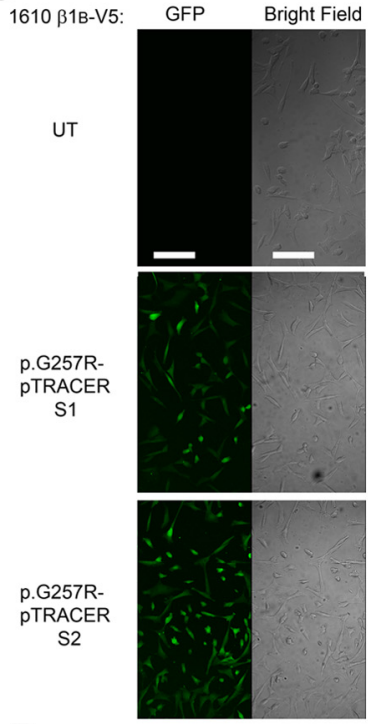

D

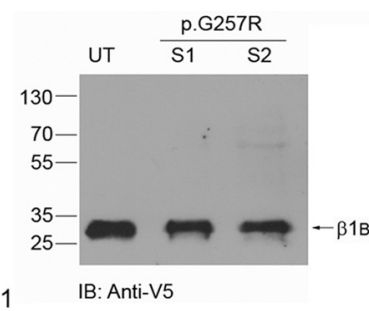

Figure 10. p.G257R does not have dominant-negative effects on wild-type $\beta 1$ or $\beta 1 \mathrm{~B}$ expression. $\boldsymbol{A}$, Confirmation of expression of $\beta 1$ in pTRACER-CMV2 in $1610-\beta 1 V 5$ cells. 1610 $\beta 1 V 5$ cells were stably transfected with the pTRACER-CMV2 construct, fixed with $4 \%$ paraformaldehyde, and monitored for GFP fluorescence (left panels) and bright-field images (right panels), as indicated, using confocal microscopy. UT indicates untransfected cells. Scale bars, $100 \mu \mathrm{m} . \boldsymbol{B}, \beta 1 \mathrm{~B}$ p.G257R does not inhibit the cell surface expression of $\beta 1$ or $\beta 1 \mathrm{~B}$. Top panel, Surface biotinylation of 1610 cells stably coexpressing V5-tagged $\beta 1$ and either $\beta 1 B$ or p.G257R. 1610- $\beta 1$ V 5 cells (UT lane) show normal surface expression of $\beta 1$. Bottom panel, Western blot of the same samples probed with anti-Na ${ }^{+} / \mathrm{K}^{+}$ATPase $\beta 1$ show equal loading of surface proteins. $C$, Confirmation of expression of p.G257R in pTRACER-CMV2 in 1610- $\beta 1$ BVV 5 cells. $1610-\beta 1 B V 5$ cells were stably transfected with the PTRACER-CMV2 construct, fixed with $4 \%$ paraformaldehyde, and monitored for GFP fluorescence (leftpanels) and bright-field images (right panels), as indicated, using confocal microscopy. UT indicates untransfected cells. Scale bars, $100 \mu \mathrm{m} . \boldsymbol{D}$, p.G257R does not inhibit secretion of $\beta 1 B$. Conditioned media from two independent cell clones coexpressing $\beta 1$ BV5 and p.G257R (p.G257RS1 and S2) were collected and analyzed by Western blot with anti-V5. Conditioned media from 1610- $\beta 1$ BV5 cells (UT) was a positive control.

monolayers had mean neurite lengths that were indistinguishable from those plated on untransfected 1610 cells (1610-p.G257RV5, $40.87 \pm 1.56 \mu \mathrm{m}$, vs $1610,35.96 \pm 1.63 \mu \mathrm{m} ; n=300$ and 200 , respectively) and significantly shorter than CGNs plated on 1610$\beta 1 \mathrm{~V} 5(70.02 \pm 2.07 \mu \mathrm{m} ; n=300)$ or $1610-\beta 1 \mathrm{BV} 5(65.89 \pm 2.31$ $\mu \mathrm{m} ; n=300 ; p<0.001$ ) (Fig. 9D). These results demonstrate that p.G257R is a functional null allele.

To test whether p.G257R may inhibit $\beta 1$ cell surface expression via a dominant-negative function, $1610-\beta 1 \mathrm{~V} 5$ cells were stably transfected with cDNA encoding either $\beta 1 \mathrm{~B}$ or p.G257R in pTRACER-CMV2. This plasmid encodes EGFP under control of a separate promoter than that used for the multiple cloning site. After stable transfection, $>99 \%$ of the $1610-\beta 1$ V5 cells coexpressing $\beta 1 \mathrm{~B}$ or $\mathrm{p} . \mathrm{G} 257 \mathrm{R}$ showed green fluorescence, confirming $\beta 1 \mathrm{~B}$ or p.G257R protein expression (Fig. $10 \mathrm{~A}, \mathrm{C}$ ). Surface bioti- 


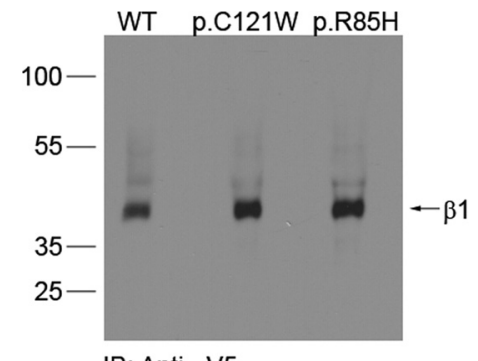

IB: Anti - V5

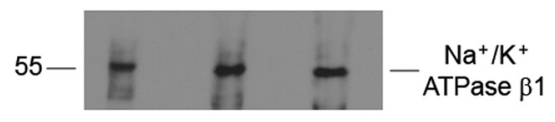

IB: Anti - $\mathrm{Na}^{+} / \mathrm{K}^{+}$ATPase $\beta 1$

Figure 11. SCN1B p.C121W and p.R85H are expressed at the cell surface. Top panel, Western blot showing surface biotinylation of 1610 cells stably transfected with V5-His-tagged $\beta 1$ wildtype (WT), V5-His-tagged $\beta 1$ p.C121W, or V5-His-tagged $\beta 1$ p.R85H. Bottom panel, Western blot of the same samples with anti-Na ${ }^{+} / \mathrm{K}^{+}$ATPase $\beta 1$ showed equal loading of surface proteins.

nylation assays were subsequently performed on $1610-\beta 1 \mathrm{~V} 5$ cells or $1610-\beta 1 \mathrm{~V} 5$ cells coexpressing either wild-type $\beta 1 \mathrm{~B}$ or p.G257R in pTRACER-CMV2. Surface expression of $\beta 1 V 5$ was detected by probing the Western blots with anti-V 5 antibody. All lanes showed similar levels of $\beta 1 \mathrm{~V} 5$ surface expression, indicating that coexpression of $\beta 1 \mathrm{~B}$ or p.G257R did not interfere with $\beta 1$ trafficking to the plasma membrane (Fig. $10 \mathrm{~B}$ ). A similar strategy was used to assess whether p.G257R functioned as a dominant negative for wild-type $\beta 1 \mathrm{~B}$ secretion. Stably transfected 1610$\beta 1 \mathrm{BV} 5$ cells were transfected with p.G257R in pTRACER-CMV2 (Fig. 10C). Western blots of conditioned media were probed with anti-V5 to detect wild-type $\beta 1 \mathrm{~B}$ secretion. Conditioned media collected from $1610-\beta 1 B V 5$ cells were used as a positive control. Comparable levels of anti-V5-immunoreactive bands were detected in all lanes, demonstrating that p.G257R does not interfere with wild-type $\beta 1 \mathrm{~B}$ secretion (Fig. $10 D$ ).

\section{Are other SCN1B epilepsy-linked mutations trafficking deficient?}

SCN1B p.R125C (Patino et al., 2009) and p.G257R (above) are retained intracellularly. Is this a general mechanism of $S C N 1 B-$ linked epilepsy? To test this possibility, we expressed SCN1B p.C121W (Wallace et al., 2002b) and p.R85H (Xu et al., 2007) in 1610 cells and performed surface biotinylation assays as described for Figure 3. As shown in Figure 11, in contrast to p.R125C and p.G257R and in agreement with our previous study of p.C121W (Meadows et al., 2002b), both of these mutants were observed to be robustly expressed at the cell surface. Thus, at least in heterologous cells, intracellular retention resulting in a functional null phenotype is not a general mechanism of SCN1Blinked epilepsy.

\section{Discussion}

Despite an extensive literature demonstrating dramatic effects of $\beta 1$-subunit coexpression on $\mathrm{Na}^{+}$current in heterologous systems, the major role of $S C N 1 B$ in vivo appears to be cell adhesion (Patino and Isom, 2010). Studies with Scn1b-null mice show that this gene plays significant roles in promoting neuronal migration, neurite extension, and axonal fasciculation in brain and corticospinal tract (Brackenbury et al., 2008a, 2010). While many studies have shown dramatic Scn $1 b$-mediated $\mathrm{Na}^{+}$current modulation in heterologous systems in vitro (for review, see Patino and Isom, 2010), the observed effects of Scn1b deletion or mutation on $\mathrm{Na}^{+}$current in vivo are neuronal cell type specific and more subtle than observed in Xenopus oocytes or transfected cells (Chen et al., 2004; Aman et al., 2009; Brackenbury et al., 2010; Uebachs et al., 2010; Wimmer et al., 2010). It is important to consider, however, that multiplication of these small effects through synaptic networks may result in large changes in excitability in vivo. $\mathrm{Na}^{+}$current is required for $\mathrm{Scn} 1 b$-mediated neurite outgrowth (Brackenbury et al., 2010), but we argue that $S c n 1 b$-mediated modulation of $\mathrm{Na}^{+}$current is not. Localization of $\mathrm{Na}_{\mathrm{v}} 1.6$ to the axon initial segment is modulated by $S c n 1 b$ and is critical for $S c n 1 b$-mediated neurite outgrowth in CGNs (Brackenbury et al., 2010). However, this effect is likely attributed to $S c n 1 b$-mediated cell-adhesive interactions and not Scn $1 b$ mediated $\mathrm{Na}^{+}$current modulation. Clearly, Scn1b plays multifunctional signaling roles in vivo. A critical future experiment will be to separate the effects of $S c n 1 b$ on $\mathrm{Na}^{+}$current modulation from those on cell adhesion to assess their relative impacts in brain in vivo.

The present results emphasize that understanding the physiological role of SCN1B in brain must include consideration of the structure and function of $\beta 1 \mathrm{~B}$ in addition to $\beta 1$. This is underappreciated in the field, as most studies have considered only $\beta 1$. Our results showing that $\beta 1 \mathrm{~B}$ is a secreted CAM expressed in embryonic brain that exerts only subtle effects on neuronal VGSC $\alpha$-subunits suggest that this splice variant may play critical roles in $S C N 1 B$ function during brain development through nonconducting cell adhesive mechanisms. Interestingly, because $\beta 1 \mathrm{~B}$ is a secreted protein, it may play autocrine or paracrine roles in neuronal pathfinding. Deletion of $\beta 1 \mathrm{~B}$ may make a significant contribution to the severe neurological $S c n 1 b$-null phenotype. This phenotype includes not only $S c n 1 b$-null mice but also the functional null $S C N 1 B$ p.R125C mutation linked to Dravet syndrome in humans (Patino et al., 2009). Before the present study, all reported $S C N 1 B$ mutations associated with human epilepsy were found to be located in the Ig domain that is shared between $\beta 1$ and $\beta 1 \mathrm{~B}$. These results suggest that cell adhesion is clinically relevant and, importantly, that disruption of either splice variant may result in human brain disease. Novel evidence provided here demonstrates that $\beta 1 \mathrm{~B}$ p.G257R (located in the retained intronic region unique to $\beta 1 \mathrm{~B}$ ) may be a risk factor for human epilepsy, suggesting that $\beta 1 \mathrm{~B}$ is a critical player in brain development.

CAMs are critical for normal nervous system development and for synaptic plasticity in adulthood. Dysregulation of neural cell adhesion molecule (NCAM) expression or signaling is associated with a number of brain disorders, including depression, anxiety, bipolar disorder, and schizophrenia (for review, see Brennaman and Maness, 2010). Deletion of Nr-CAM (neuronal cell adhesion molecule) in mice results in an altered behavioral phenotype reflective of increased impulsivity (Matzel et al., 2008). Deletion of the CAM Lsamp in mice leads to heightened reactivity to novelty (Catania et al., 2008) and conditional deletion of L1-CAM in brain results in decreased anxiety-like behavior (Law et al., 2003). Epilepsy and neuropsychiatric disease have a bidirectional relationship of comorbidity (Dixon-Salazar et al., 2004; Gargus, 2006; Jacoby and Thapar, 2009; Pauli and Stefan, 2009; Spence and Schneider, 2009) and thus may share common genetic mechanisms. SCN1B-dependent regulation of neuronal pathfinding may be critical to abnormal brain development in both neurological and psychiatric disease. Expression of multiple $S C N 1 B$ splice variants, including a secreted form, is also consistent with other members of the Ig superfamily of CAMs (Rougon and Hobert, 2003; Jones et al., 2009). For example, increased 
expression of secreted forms of NCAM is associated with bipolar disorder and depression (Brennaman and Maness, $2010)$. In a similar way, modulation of $\beta 1 \mathrm{~B}$ secretion may have pathological consequences in brain, as suggested here for $\beta 1 \mathrm{~B}$ p.G257R.

We did not detect biochemical association of human $\beta 1 \mathrm{~B}$ with human $\mathrm{Na}_{\mathrm{v}} 1.1, \mathrm{Na}_{\mathrm{v}} 1.3$, or $\mathrm{Na}_{\mathrm{v}} 1.5$. Despite this, coexpression of $\mathrm{Na}_{\mathrm{v}} 1.3$ and $\beta 1 \mathrm{~B}$ revealed subtle changes in $\mathrm{Na}^{+}$current, similar to our previously published results with rat $\beta 1 \mathrm{~B}$ and $\mathrm{Na}_{\mathrm{v}} 1.2$ (Kazen-Gillespie et al., 2000), suggesting that $\beta 1 \mathrm{~B}$ may associate weakly or transiently with VGSC $\alpha$-subunits and play a minor current modulatory role in brain. We observed that $\beta 1 \mathrm{~B}$ was sequestered at the cell surface by $\mathrm{Na}_{\mathrm{v}} 1.5$ but not by $\mathrm{Na}_{\mathrm{v}} 1.1$ or $\mathrm{Na}_{\mathrm{v}} 1.3$. Thus, the association between $\beta 1 \mathrm{~B}$ and $\mathrm{Na}_{\mathrm{v}} 1.5$ may be stronger than between $\beta 1 \mathrm{~B}$ and the tetrodotoxin-sensitive channels, in agreement with a previous study showing modulation of $\mathrm{Na}_{\mathrm{v}} 1.5$ current density in heterologous cells by $\beta 1 \mathrm{~B}$ and that a $S C N 1 B$ mutation linked to Brugada syndrome disrupts the $\mathrm{Na}^{+}$ current modulatory properties of $\beta 1 \mathrm{~B}$ (Watanabe et al., 2008). In addition to heart, $\mathrm{Na}_{\mathrm{v}} 1.5$ is expressed in a population of limbic neurons in brain (Hartmann et al., 1999). Differential $\beta 1 \mathrm{~B}$ expression in specific brain areas may result in diverse effects on excitability and neurite outgrowth depending on which VGSC $\alpha$-subunits are coexpressed or perhaps upregulated in response to pathology (Waxman, 2006). These data, in concert with our recent results showing specific partnering of $\mathrm{Na}_{\mathrm{v}} 1.6$ and $\beta 1$ subunits in cerebellum (Brackenbury et al., 2010), raise the possibility that certain VGSC $\alpha$ - and $\beta$-subunits form selective partnerships in excitable cells.

$S C N 1 B$ p.G257R results in intracellular retention of $\beta 1 \mathrm{~B}$, generating a functional null cellular phenotype. This mechanism is consistent with that of p.R125C, linked to Dravet syndrome, which results in intracellular retention of $\beta 1$ and, presumably, $\beta 1 \mathrm{~B}$ as well (Patino et al., 2009). Despite this commonality, we demonstrate here that p.C121W and p.R85H are normally trafficked in heterologous cells, suggesting that intracellular retention is not a shared mechanism of $S C N 1 B$ epilepsy mutations. These results agree with our previous results in heterologous cells (Meadows et al., 2002b), but contrast with $\beta 1$ (C121W) knock-in mice, in which p.C121W appears to be retained inside the neuron (Wimmer et al., 2010). Trafficking of this mutant subunit may differ in brain neurons compared with transfected fibroblasts. Alternatively, p.C121W may be transiently trafficked to the cell surface in both cell types, but then rapidly endocytosed due to protein misfolding or lack of cell-adhesive properties (Meadows et al., 2002b).

For p.R125C and p.G257R, retention of these subunits in the cytoplasm may inhibit signaling or trafficking of other proteins or induce cellular stress leading to neural degeneration. Thus, $S C N 1 B$ gene dosage may be critical for brain disease. Heterozygous expression of one mutant and one wild-type $S C N 1 B$ allele results in mild to moderate GEFS + spectrum disorders with incomplete penetrance in human patients, with symptom severity likely depending on genetic background and/or epigenetic factors. In this sense, the pedigrees presented in our study are similar to those reported previously (Scheffer et al., 2007; Watanabe et al., 2008). In contrast, inheritance of two mutant $S C N 1 B$ alleles affecting the region common to $\beta 1$ and $\beta 1 \mathrm{~B}$ and resulting in intracellular retention causes Dravet syndrome, the most severe, and sometimes fatal, disorder of the GEFS + spectrum (Patino et al., 2009). If, as predicted by the present data, secreted $\beta 1 \mathrm{~B}$ regulates neurite extension in developing human brain through celladhesive interactions, gene dosage will be critically important, as varying levels of $S C N 1 B$ expression are predicted to regulate gradients of $\beta 1 \mathrm{~B}$ in the extracellular matrix, which may then serve as attractive or repulsive signals. The contribution of $\beta 1 \mathrm{~B}$ to brain development is not yet known; however, our results shed new light on the role of this subunit in SCN1B function and present a fresh perspective on the biology of these multifunctional subunits.

\section{References}

Aman TK, Grieco-Calub TM, Chen C, Rusconi R, Slat EA, Isom LL, Raman IM (2009) Regulation of persistent Na current by interactions between $\beta$ subunits of voltage-gated $\mathrm{Na}$ channels. J Neurosci 29:2027-2042.

Bourgeois S, Labuda D (2004) Dynamic allele-specific oligonucleotide hybridization on solid support. Anal Biochem 324:309-311.

Brackenbury WJ, Davis TH, Chen C, Slat EA, Detrow MJ, Dickendesher TL, Ranscht B, Isom LL (2008a) Voltage-gated $\mathrm{Na}^{+}$channel $\beta 1$ subunitmediated neurite outgrowth requires Fyn kinase and contributes to postnatal CNS development in vivo. J Neurosci 28:3246-3256.

Brackenbury WJ, Djamgoz MB, Isom LL (2008b) An emerging role for voltage-gated $\mathrm{Na}^{+}$channels in cellular migration: regulation of central nervous system development and potentiation of invasive cancers. Neuroscientist 14:571-583.

Brackenbury WJ, Calhoun JD, Chen C, Miyazaki H, Nukina N, Oyama F, Ranscht B, Isom LL (2010) Functional reciprocity between $\mathrm{Na}^{+}$channel Nav1.6 and betal subunits in the coordinated regulation of excitability and neurite outgrowth. Proc Natl Acad Sci U S A 107:2283-2288.

Brennaman LH, Maness PF (2010) NCAM in neuropsychiatric and neurodegenerative disorders. Adv Exp Med Biol 663:299-317.

Catania EH, Pimenta A, Levitt P (2008) Genetic deletion of Lsamp causes exaggerated behavioral activation in novel environments. Behav Brain Res 188:380-390.

Catterall WA, Goldin AL, Waxman SG (2005) International Union of Pharmacology. XLVII. Nomenclature and structure-function relationships of voltage-gated sodium channels. Pharmacol Rev 57:397-409.

Chen C, Westenbroek RE, Xu X, Edwards CA, Sorenson DR, Chen Y, McEwen DP, O’Malley HA, Bharucha V, Meadows LS, Knudsen GA, Vilaythong A, Noebels JL, Saunders TL, Scheuer T, Shrager P, Catterall WA, Isom LL (2004) Mice lacking sodium channel $\beta 1$ subunits display defects in neuronal excitability, sodium channel expression, and nodal architecture. J Neurosci 24:4030-4042.

Claros MG, von Heijne G (1994) TopPred II: an improved software for membrane protein structure predictions. Comput Appl Biosci 10:685-686.

Davis TH, Chen C, Isom LL (2004) Sodium channel $\beta 1$ subunits promote neurite outgrowth in cerebellar granule neurons. J Biol Chem 279:51424-51432.

Dib-Hajj SD, Waxman SG (1995) Genes encoding the $\beta 1$ subunit if voltagedependent $\mathrm{Na}^{+}$channel in rat, mouse and human condition conserved introns. FEBS Lett 377:485-488.

Dixon-Salazar TJ, Keeler LC, Trauner DA, Gleeson JG (2004) Autism in several members of a family with generalized epilepsy with febrile seizures plus. J Child Neurol 19:597-603.

Gargus JJ (2006) Ion channel functional candidate genes in multigenic neuropsychiatric disease. Biol Psychiatry 60:177-185.

Hartmann HA, Colom LV, Sutherland ML, Noebels JL (1999) Selective localization of cardiac SCN5A sodium channels in limbic regions of rat brain. Nature 2:593-595.

Isom LL, De Jongh KS, Patton DE, Reber BF, Offord J, Charbonneau H, Walsh K, Goldin AL, Catterall WA (1992) Primary structure and functional expression of the $\beta 1$ subunit of the rat brain sodium channel. Science 256:839-842.

Isom LL, Scheuer T, Brownstein AB, Ragsdale DS, Murphy BJ, Catterall WA (1995) Functional co-expression of the $\beta 1$ and type IIA $\alpha$ subunits of sodium channels in a mammalian cell line. J Biol Chem 270:3306-3312.

Jacoby A, Thapar A (2009) The contribution of seizures to psychosocial ill-health. Epilepsy Behav 15 [Suppl 1]:S41-S45.

Jones DC, Roghanian A, Brown DP, Chang C, Allen RL, Trowsdale J, Young NT (2009) Alternative mRNA splicing creates transcripts encoding soluble proteins from most LILR genes. Eur J Immunol 39:3195-3206.

Kazen-Gillespie KA, Ragsdale DS, D’Andrea MR, Mattei LN, Rogers KE, Isom LL (2000) Cloning, localization, and functional expression of sodium channel $\beta 1$ A subunits. J Biol Chem 275:1079-1088. 
Law JW, Lee AY, Sun M, Nikonenko AG, Chung SK, Dityatev A, Schachner M, Morellini F (2003) Decreased anxiety, altered place learning, and increased CA1 basal excitatory synaptic transmission in mice with conditional ablation of the neural cell adhesion molecule L1. J Neurosci 23:10419-10432.

Lopez-Santiago LF, Meadows LS, Ernst SJ, Chen C, Malhotra JD, McEwen DP, Speelman A, Noebels JL, Maier SK, Lopatin AN, Isom LL (2007) Sodium channel SCN1B null mice exhibit prolonged QT and RR intervals. J Mol Cell Cardiol 43:636-647.

Makielski JC, Ye B, Valdivia CR, Pagel MD, Pu J, Tester DJ, Ackerman MJ (2003) A ubiquitous splice variant and a common polymorphism affect heterologous expression of recombinant human SCN5A heart sodium channels. Circ Res 93:821-828.

Malhotra JD, Kazen-Gillespie K, Hortsch M, Isom LL (2000) Sodium channel $\beta$ subunits mediate homophilic cell adhesion and recruit ankyrin to points of cell-cell contact. J Biol Chem 275:11383-11388.

Malhotra JD, Koopmann MC, Kazen-Gillespie KA, Fettman N, Hortsch M, Isom LL (2002) Structural requirements for interaction of sodium channel $\beta 1$ subunits with ankyrin. J Biol Chem 277:26681-26688.

Matzel LD, Babiarz J, Townsend DA, Grossman HC, Grumet M (2008) Neuronal cell adhesion molecule deletion induces a cognitive and behavioral phenotype reflective of impulsivity. Genes Brain Behav 7:470-480.

McEwen DP, Isom LL (2004) Heterophilic interactions of sodium channel beta 1 subunits with axonal and glial cell adhesion molecules. J Biol Chem 279:52744-52752.

McEwen DP, Meadows LS, Chen C, Thyagarajan V, Isom LL (2004) Sodium channel $\beta 1$ subunit-mediated modulation of Nav1.2 currents and cell surface density is dependent on interactions with contactin and ankyrin. J Biol Chem 279:16044-16049.

McEwen DP, Chen C, Meadows LS, Lopez-Santiago L, Isom LL (2009) The voltage-gated $\mathrm{Na}^{+}$channel $\beta 3$ subunit does not mediate trans homophilic cell adhesion or associate with the cell adhesion molecule contactin. Neurosci Lett 462:272-275.

Meadows LS, Chen YH, Powell AJ, Clare JJ, Ragsdale DS (2002a) Functional modulation of human brain Nav1.3 sodium channels, expressed in mammalian cells, by auxiliary beta 1, beta 2 and beta 3 subunits. Neuroscience 114:745-753.

Meadows LS, Malhotra J, Loukas A, Thyagarajan V, Kazen-Gillespie KA, Koopman MC, Kriegler S, Isom LL, Ragsdale DS (2002b) Functional and biochemical analysis of a sodium channel $\beta 1$ subunit mutation responsible for generalized epilepsy with febrile seizures plus type 1. J Neurosci 22:10699-10709.

Meisler MH, O'Brien JE, Sharkey LM (2010) Sodium channel gene family: epilepsy mutations, gene interactions and modifier effects. J Physiol 588:1841-1848.

Oh Y, Waxman SG (1994) The beta 1 subunit mRNA of the rat brain $\mathrm{Na}^{+}$ channel is expressed in glial cells. Proc Natl Acad Sci U S A 91:9985-9989.

Patino GA, Isom LL (2010) Electrophysiology and beyond: multiple roles of $\mathrm{Na}^{+}$channel beta subunits in development and disease. Neurosci Lett 486:53-59.

Patino GA, Claes LR, Lopez-Santiago LF, Slat EA, Dondeti RS, Chen C, O’Malley HA, Gray CB, Miyazaki H, Nukina N, Oyama F, De Jonghe P, Isom LL (2009) A functional null mutation of SCN1B in a patient with Dravet syndrome. J Neurosci 29:10764-10778.

Pauli E, Stefan H (2009) Emotional and affective disorders, anxiety and personality disorders in epilepsies (in German). Nervenarzt 80:1440-1451.
Qin N, D’Andrea MR, Lubin ML, Shafaee N, Codd EE, Correa AM (2003) Molecular cloning and functional expression of the human sodium channel betalB subunit, a novel splicing variant of the betal subunit. Eur J Biochem 270:4762-4770.

Remme CA, Wilde AA, Bezzina CR (2008) Cardiac sodium channel overlap syndromes: different faces of SCN5A mutations. Trends Cardiovasc Med 18:78-87.

Rougon G, Hobert O (2003) New insights into the diversity and function of neuronal immunoglobulin superfamily molecules. Annu Rev Neurosci 26:207-238

Ruan Y, Liu N, Priori SG (2009) Sodium channel mutations and arrhythmias. Nat Rev Cardiol 6:337-348.

Scheffer IE, Harkin LA, Grinton BE, Dibbens LM, Turner SJ, Zielinski MA, Xu R, Jackson G, Adams J, Connellan M, Petrou S, Wellard RM, Briellmann RS, Wallace RH, Mulley JC, Berkovic SF (2007) Temporal lobe epilepsy and GEFS+ phenotypes associated with SCN1B mutations. Brain 130:100-109.

Spence SJ, Schneider MT (2009) The role of epilepsy and epileptiform EEGs in autism spectrum disorders. Pediatr Res 65:599-606.

Thompson JD, Higgins DG, Gibson TJ (1994) CLUSTAL W: improving the sensitivity of progressive multiple sequence alignment through sequence weighting, position-specific gap penalties and weight matrix choice. Nucleic Acids Res 22:4673-4680.

Uebachs M, Opitz T, Royeck M, Dickhof G, Horstmann MT, Isom LL, Beck H (2010) Efficacy loss of the anticonvulsant carbamazepine in mice lacking sodium channel $\beta$ subunits via paradoxical effects on persistent sodium current. J Neurosci 30:8489-8501.

von Heijne G (1992) Membrane protein structure prediction. Hydrophobicity analysis and the positive-inside rule. J Mol Biol 225:487-494.

Wallace RH, Scheffer IE, Parasivam G, Barnett S, Wallace GB, Sutherland GR, Berkovic SF, Mulley JC (2002) Generalized epilepsy with febrile seizures plus: mutation of the sodium channel subunit SCN1B. Neurology 58:1426-1429.

Watanabe H, Koopmann TT, Le Scouarnec S, Yang T, Ingram CR, Schott JJ, Demolombe S, Probst V, Anselme F, Escande D, Wiesfeld AC, Pfeufer A, Kääb S, Wichmann HE, Hasdemir C, Aizawa Y, Wilde AA, Roden DM, Bezzina CR (2008) Sodium channel betal subunit mutations associated with Brugada syndrome and cardiac conduction disease in humans. J Clin Invest 118:2260-2268.

Watanabe H, Darbar D, Kaiser DW, Jiramongkolchai K, Chopra S, Donahue BS, Kannankeril PJ, Roden DM (2009) Mutations in sodium channel $\beta 1$ - and $\beta 2$-subunits associated with atrial fibrillation. Circ Arrhythm Electrophysiol 2:268-275.

Waxman SG (2006) Ions, energy and axonal injury: towards a molecular neurology of multiple sclerosis. Trends Mol Med 12:192-195.

Wimmer VC, Reid CA, Mitchell S, Richards KL, Scaf BB, Leaw BT, Hill EL, Royeck M, Horstmann MT, Cromer BA, Davies PJ, Xu R, Lerche H, Berkovic SF, Beck H, Petrou S (2010) Axon initial segment dysfunction in a mouse model of genetic epilepsy with febrile seizures plus. J Clin Invest 120:2661-2671.

Xu R, Thomas EA, Gazina EV, Richards KL, Quick M, Wallace RH, Harkin LA, Heron SE, Berkovic SF, Scheffer IE, Mulley JC, Petrou S (2007) Generalized epilepsy with febrile seizures plus-associated sodium channel beta1 subunit mutations severely reduce beta subunit-mediated modulation of sodium channel function. Neuroscience 148:164-174. 